\title{
Evaluation of Natural Radioactivity in Marine Sand Deposits from Offshore China
}

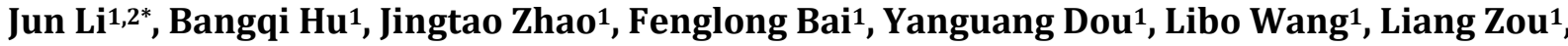 \\ Xue Ding1
}

\footnotetext{
${ }^{1}$ Key Laboratory of Marine Hydrocarbon Resources and Environmental Geology of Ministry of Land and Resources, Qingdao Institute of Marine Geology, Qingdao, China

${ }^{2}$ Laboratory for Marine Mineral Resources, Qingdao National Laboratory of Marine Science and Technology, Qingdao, China Email: *junli741001@gmail.com
}

How to cite this paper: $\mathrm{Li}, \mathrm{J} . \mathrm{Hu}, \mathrm{B} . \mathrm{Q}$., Zhao, J.T., Bai, F.L., Dou, Y.G., Wang, L.B., Zou, L. and Ding, X. (2017) Evaluation of Natural Radioactivity in Marine Sand Deposits from Offshore China. Open Journal of Marine Science, 7, 357-378.

https://doi.org/10.4236/ojms.2017.73026

Received: April 3, 2017

Accepted: July 9, 2017

Published: July 12, 2017

Copyright $\odot 2017$ by authors and Scientific Research Publishing Inc. This work is licensed under the Creative Commons Attribution International License (CC BY 4.0).

http://creativecommons.org/licenses/by/4.0/

\begin{abstract}
Natural radioactivity is very important for the assessment of the marine sand property and usability. By using gamma spectrometry, the concentration of the natural radionuclides ${ }^{226} \mathrm{Ra},{ }^{232} \mathrm{Th}$ and ${ }^{40} \mathrm{~K}$ have been measured in marine sand deposits from Liaodong Bay (LDB), North Yellow Sea (NYS), Zhoushan area (ZS), Taiwan Shoal (TS) and Pearl River Mouth (PR), offshore China, which are potential marine sand mining areas. The radiation activity equivalent (Raeq), indoor gamma absorbed dose rate (DR), annual effective dose (HR), alpha index (Ia), gamma index (Ig), external radiation hazard index (Hex), internal radiation hazard index (Hin), representative level index (RLI), excess lifetime cancer risk (ELCR) and annual gonadal dose equivalent (AGDE) associated with the natural radionuclides are calculated to assess the radiation hazard of the natural radioactivity in the marine sands offshore China. From the analysis, it is found that these marine sands are safe for the constructions. The Pearson correlation coefficient reveals that the ${ }^{226} \mathrm{Ra}$ distribution in the marine sands offshore China is controlled by the variation of the ${ }^{40} \mathrm{~K}$ concentration. Principal component analysis (PCA) yields a two-component representation of the entire data from the marine sands, wherein $98.22 \%$ of the total variance is explained. Our results provide good baseline data to expand the database of radioactivity of building materials in China and all over the world.
\end{abstract}

\section{Keywords}

Natural Radioactivity, Radiation Hazard, Principal Component Analysis, Gamma Spectrometry, Marine Sand, Offshore China

\section{Introduction}

With the exhausting on-land sand resources and increasing environmental pres- 
sure, it has become necessary to look for alternative sources. Marine sand resources now stand for a more promising alternative, and contribute significantly to the overall provision of sand material in many countries (e.g., [1] [2] [3]). It was widely utilized as the main construction materials for buildings, road, artificial islands, coastal reclamation and beach nourishment, etc. Today, marine sand mining has become the second most important marine mining activity after offshore oil extraction [1] [3]. The annual global production of the aggregate is about 16.5 billion tons, of which approximately $10 \%$ is supplied by marine sand mining in coastal waters [4].

Together with the rapid economic development of China, the unprecedented demand for the marine sand mining has increased greatly in the recent years. After nearly 10 years of extensive exploration of marine sand offshore China, there are five areas were assessed which are suitable for marine sand mining, namely Liaodong Bay (LB), North Yellow Sea (NYS), Zhoushan Area (ZS), Taiwan Shoal (TS) and Pearl River Mouth (PR) (Figure 1), where very large quantity of sandy sediments developed.

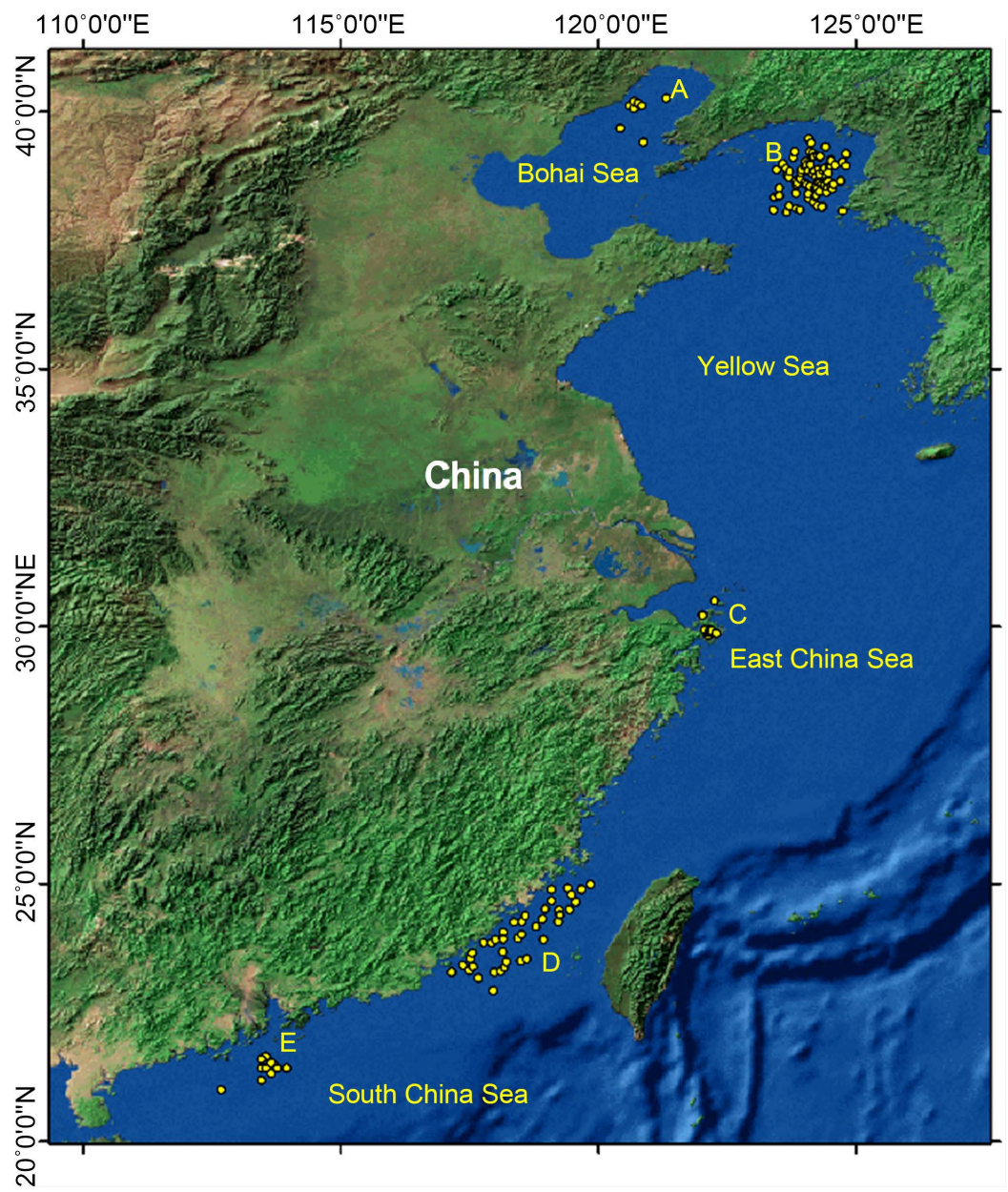

Figure 1. Locations of samples (solid yellow dots) and study areas offshore China in this study. A, Liaodong Bay (LDB); B, North Yellow Sea (NYS); C, Zhoushan Area (ZS); D, Taiwan Shoal (TS); E, Pearl River Mouth (PR). The geographic coordinate of the samples are shown in Table 1. 
However, the quality of marine sand should be scientifically evaluated before the mining and utilization. The quality parameters include the grain-size composition and sorting, heavy metal constituents, the mineral components, and most importantly, the natural radioactive properties $\left({ }^{226} \mathrm{Ra},{ }^{232} \mathrm{Th}\right.$ and $\left.{ }^{40} \mathrm{~K}\right)$. The study of the concentrations of radionuclides and their distribution in sands enables the assessment of radiological risk due to external human exposure to gamma radiation outdoors and inhalation of airborne radioactivity emanating from building constructions and dwellings (e.g., [5] [6]). Generally, the specific activities of ${ }^{226} \mathrm{Ra},{ }^{232} \mathrm{Th}$ and ${ }^{40} \mathrm{~K}$ in raw building materials and their products depend on their geological and geographical conditions as well as the geochemical features of those materials [7]. And the natural radioactivity of marine sand depends on the sediment formation and transport processes that were involved; chemical and biochemical interactions influence the distribution patterns of uranium, thorium and their decay products. However, many studies had been carried out on the radionuclide concentrations in sand beaches around the world, such as India [8] [9], Brazil [10] [11], Thailand [12], Egypt [13], Iran [14], and China (Xiamen, [15]) using the gamma ray spectrometry. In spite of the high number of works carried out around the world on the beach sands, there is a lack of studies about radionuclides of offshore sands.

The aim of this study is to determine natural radioactivity $\left({ }^{226} \mathrm{Ra},{ }^{232} \mathrm{Th},{ }^{40} \mathrm{~K}\right)$ levels in sandy sediments (potential marine sand resources) collected from offshore China. Also, the average radium equivalent activity (Raeq), the total absorbed dose rate (D), the indoor and external hazard index (Hin, Hex), the annual gonadal dose equivalent (AGDE) and the annual effective dose equivalent (AEDE), etc., which will be defined later have been calculated and compared with the results of beach sands in literature all over the world. The results of this study will provide background data on the natural radioactive isotopes and environmental pollution of marine sand deposits offshore China.

\section{Materials and Methods}

Totally 141 sandy sediments were collected in five potential marine sand deposits offshore China, in which 8 samples are from Liaodong Bay, 68 samples from North Yellow Sea, 12 samples from Zhoushan Area, 41 samples from Taiwan Shoal and 12 samples from Pearl River Mouth, respectively. The locations of each sample were shown in Figure 1 and Table 1. The water depths of the samples range from $10 \mathrm{~m}$ to $50 \mathrm{~m}$.

After all samples were dried at room temperature, samples were pulverized by Retsch mill and sieved through a 100 mesh to be homogenized, then weighed and transferred to Marinelli beakers of $1000 \mathrm{ml}$ volume. Each sample was sealed for 30 days to reach radioactive equilibrium where the decay rate of the daughters becomes equal to that of the parent [16]. Sample preparation and all radioactivity measurements were carried out by using a Gamma-ray spectrometer (BE3830, Canbarra Industries, Inc.) in Qingdao Institute of Marine Geology. Gamma-ray spectrometer was used to determine the activities of ${ }^{226} \mathrm{Ra},{ }^{232} \mathrm{Th}$ and 
Table 1. Location and Activity concentration $\left(\mathrm{Bq} \cdot \mathrm{kg}^{-1}\right)$ of ${ }^{226} \mathrm{Ra},{ }^{232} \mathrm{Th}$, and ${ }^{40} \mathrm{~K}$ in marine sands offshore China.

\begin{tabular}{|c|c|c|c|c|c|}
\hline \multirow{2}{*}{ Sample ID } & \multicolumn{2}{|c|}{ Location } & \multicolumn{3}{|c|}{ Activity concentration $\left(\mathrm{Bq} \cdot \mathrm{kg}^{-1}\right)$} \\
\hline & $\mathrm{X}$ & $\mathrm{Y}$ & ${ }^{226} \mathrm{Ra}$ & ${ }^{232} \mathrm{Th}$ & ${ }^{40} \mathrm{~K}$ \\
\hline \multicolumn{6}{|c|}{ Liaodong Bay } \\
\hline LDB-1 & 120.42 & 39.68 & 36.1 & 43.9 & 562.0 \\
\hline LDB-2 & 120.61 & 40.11 & 14.7 & 26.3 & 873.6 \\
\hline LDB-3 & 120.68 & 40.07 & 28.5 & 56.8 & 705.5 \\
\hline LDB-4 & 120.69 & 40.20 & 32.8 & 48.1 & 752.5 \\
\hline LDB-5 & 120.77 & 40.16 & 34.9 & 53.8 & 919.5 \\
\hline LDB-6 & 120.84 & 40.11 & 17.9 & 36.0 & 405.9 \\
\hline LDB-7 & 120.87 & 39.41 & 27.7 & 44.2 & 638.8 \\
\hline LDB-8 & 121.32 & 40.25 & 19.9 & 25.3 & 677.2 \\
\hline \multicolumn{6}{|c|}{ North Yellow Sea } \\
\hline NYS-1 & 123.40 & 38.09 & 25.9 & 39.7 & 649.0 \\
\hline NYS-2 & 123.41 & 38.33 & 27.4 & 51.2 & 635.0 \\
\hline NYS-3 & 123.46 & 38.86 & 32.7 & 68.4 & 1044.0 \\
\hline NYS-4 & 123.51 & 38.37 & 37.4 & 82.5 & 803.0 \\
\hline NYS-5 & 123.51 & 38.51 & 37.3 & 80.0 & 841.0 \\
\hline NYS-6 & 123.58 & 38.98 & 12.2 & 24.1 & 894.0 \\
\hline NYS-7 & 123.64 & 38.89 & 36.6 & 73.7 & 847.0 \\
\hline NYS-8 & 123.65 & 38.05 & 61.2 & 82.3 & 722.0 \\
\hline NYS-9 & 123.65 & 38.78 & 14.9 & 28.6 & 959.0 \\
\hline NYS-10 & 123.68 & 38.73 & 19.8 & 50.1 & 829.6 \\
\hline NYS-11 & 123.70 & 38.17 & 22.1 & 43.1 & 922.0 \\
\hline NYS-12 & 123.71 & 38.84 & 23.9 & 55.3 & 881.0 \\
\hline NYS-13 & 123.78 & 39.11 & 13.5 & 28.4 & 776.0 \\
\hline NYS-14 & 123.81 & 39.23 & 12.4 & 23.7 & 905.0 \\
\hline NYS-15 & 123.82 & 38.65 & 21.3 & 56.9 & 830.5 \\
\hline NYS-16 & 123.83 & 38.42 & 18.9 & 44.4 & 827.1 \\
\hline NYS-17 & 123.84 & 38.59 & 20.9 & 55.3 & 816.1 \\
\hline NYS-18 & 123.85 & 38.12 & 22.5 & 43.2 & 1028.0 \\
\hline NYS-19 & 123.87 & 38.63 & 19.6 & 51.4 & 848.2 \\
\hline NYS-20 & 123.91 & 38.70 & 16.6 & 43.3 & 919.0 \\
\hline NYS-21 & 123.91 & 38.09 & 16.0 & 32.9 & 993.0 \\
\hline NYS-22 & 123.93 & 38.83 & 13.3 & 23.4 & 781.0 \\
\hline NYS-23 & 123.94 & 38.87 & 13.3 & 35.4 & 909.2 \\
\hline NYS-24 & 124.00 & 38.61 & 15.2 & 43.4 & 862.9 \\
\hline NYS- 25 & 124.01 & 38.94 & 11.9 & 26.0 & 874.7 \\
\hline
\end{tabular}


J. Li et al.

\section{Continued}

\begin{tabular}{|c|c|c|c|c|c|}
\hline NYS-26 & 124.03 & 39.04 & 15.4 & 24.0 & 904.0 \\
\hline NYS-27 & 124.04 & 38.98 & 23.7 & 60.3 & 884.9 \\
\hline NYS-28 & 124.05 & 38.59 & 18.3 & 57.2 & 854.3 \\
\hline NYS-29 & 124.07 & 38.85 & 10.3 & 27.3 & 870.7 \\
\hline NYS-30 & 124.07 & 38.31 & 15.7 & 31.5 & 833.0 \\
\hline NYS-31 & 124.07 & 38.40 & 17.6 & 40.1 & 877.0 \\
\hline NYS-32 & 124.08 & 39.48 & 18.8 & 33.3 & 841.0 \\
\hline NYS-33 & 124.10 & 39.23 & 13.3 & 26.3 & 862.0 \\
\hline NYS-34 & 124.11 & 38.56 & 22.6 & 45.8 & 850.0 \\
\hline NYS-35 & 124.12 & 38.98 & 12.7 & 25.5 & 890.0 \\
\hline NYS-36 & 124.13 & 39.40 & 16.1 & 25.2 & 805.0 \\
\hline NYS-37 & 124.14 & 38.81 & 66.3 & 175.4 & 914.0 \\
\hline NYS-38 & 124.16 & 39.19 & 16.7 & 47.4 & 891.0 \\
\hline NYS-39 & 124.17 & 39.13 & 13.0 & 31.0 & 876.1 \\
\hline NYS-40 & 124.17 & 38.25 & 11.1 & 28.1 & 890.0 \\
\hline NYS-41 & 124.19 & 38.51 & 10.1 & 30.7 & 878.3 \\
\hline NYS-42 & 124.20 & 38.84 & 12.3 & 34.2 & 848.8 \\
\hline NYS-43 & 124.20 & 38.35 & 16.3 & 27.1 & 879.0 \\
\hline NYS-44 & 124.22 & 38.74 & 14.2 & 28.7 & 816.0 \\
\hline NYS-45 & 124.22 & 38.55 & 9.8 & 24.3 & 880.4 \\
\hline NYS-46 & 124.22 & 38.39 & 24.4 & 63.4 & 819.6 \\
\hline NYS-47 & 124.25 & 38.51 & 13.8 & 39.7 & 891.0 \\
\hline NYS-48 & 124.25 & 39.14 & 19.1 & 60.9 & 873.1 \\
\hline NYS-49 & 124.25 & 38.17 & 12.9 & 25.7 & 823.0 \\
\hline NYS-50 & 124.26 & 38.64 & 14.0 & 32.8 & 907.0 \\
\hline NYS-51 & 124.27 & 38.88 & 10.1 & 19.0 & 846.0 \\
\hline NYS-52 & 124.29 & 38.63 & 7.2 & 16.7 & 836.0 \\
\hline NYS-53 & 124.29 & 38.46 & 8.3 & 21.1 & 803.9 \\
\hline NYS-54 & 124.29 & 38.79 & 11.3 & 36.5 & 828.0 \\
\hline NYS-55 & 124.30 & 39.11 & 12.8 & 36.3 & 908.2 \\
\hline NYS-56 & 124.31 & 39.14 & 13.5 & 28.1 & 958.0 \\
\hline NYS-57 & 124.34 & 38.60 & 9.3 & 24.0 & 849.0 \\
\hline NYS-58 & 124.35 & 38.16 & 18.1 & 42.7 & 865.0 \\
\hline NYS-59 & 124.36 & 38.86 & 11.1 & 24.3 & 891.7 \\
\hline NYS-60 & 124.39 & 38.57 & 7.3 & 15.7 & 797.9 \\
\hline NYS-61 & 124.39 & 38.90 & 9.4 & 23.0 & 876.2 \\
\hline NYS-62 & 124.41 & 39.31 & 11.9 & 24.3 & 944.0 \\
\hline NYS-63 & 124.42 & 38.78 & 11.9 & 34.2 & 779.0 \\
\hline
\end{tabular}




\section{Continued}

\begin{tabular}{cccccc}
\hline NYS-64 & 124.43 & 38.45 & 10.0 & 25.3 & 806.0 \\
NYS-65 & 124.43 & 38.55 & 7.4 & 17.9 & 789.7 \\
NYS-66 & 124.45 & 38.81 & 8.3 & 20.3 & 796.6 \\
NYS-67 & 124.45 & 38.65 & 7.5 & 19.6 & 781.2 \\
NYS-68 & 124.48 & 38.97 & 8.2 & 19.7 & 872.0 \\
Zhoushan Area & & & & & \\
ZS-1 & 122.02 & 30.22 & 15.1 & 36.2 & 668.0 \\
ZS-2 & 122.06 & 29.94 & 19.3 & 33.6 & 711.8 \\
ZS-3 & 122.13 & 29.85 & 19.5 & 35.3 & 665.0 \\
ZS-4 & 122.14 & 29.82 & 24.0 & 40.0 & 672.2 \\
ZS-5 & 122.15 & 29.88 & 18.2 & 35.2 & 719.1 \\
ZS-6 & 122.15 & 29.89 & 20.1 & 40.5 & 768.7 \\
ZS-7 & 122.16 & 29.94 & 21.8 & 35.7 & 680.0 \\
ZS-8 & 122.17 & 29.88 & 18.1 & 33.3 & 706.3 \\
ZS-9 & 122.19 & 29.90 & 18.3 & 36.8 & 782.1 \\
ZS-10 & 122.20 & 29.92 & 22.7 & 37.1 & 788.4 \\
ZS-11 & 122.26 & 30.50 & 20.3 & 39.9 & 740.5 \\
ZS-12 & 122.29 & 29.87 & 20.8 & 38.1 & 836.2
\end{tabular}

Taiwan Shoal

\begin{tabular}{cccccc} 
TWS-1 & 117.14 & 23.29 & 19.0 & 33.4 & 464.7 \\
TWS-2 & 117.37 & 23.42 & 21.0 & 32.0 & 572.0 \\
TWS-3 & 117.49 & 23.32 & 9.0 & 12.3 & 255.5 \\
TWS-4 & 117.52 & 23.55 & 16.0 & 19.6 & 545.3 \\
TWS-5 & 117.55 & 23.65 & 10.3 & 15.8 & 450.1 \\
TWS-6 & 117.56 & 23.39 & 14.3 & 19.1 & 489.5 \\
TWS-7 & 117.67 & 23.17 & 7.7 & 15.1 & 266.8 \\
TWS-8 & 117.67 & 23.17 & 8.5 & 14.9 & 256.9 \\
TWS-9 & 117.77 & 23.86 & 34.0 & 53.1 & 614.3 \\
TWS-10 & 117.93 & 23.86 & 36.7 & 38.7 & 637.1 \\
TWS-11 & 117.95 & 22.93 & 6.6 & 6.5 & 228.5 \\
TWS-12 & 117.98 & 23.29 & 5.6 & 7.6 & 253.4 \\
TWS-13 & 118.00 & 23.92 & 27.0 & 35.4 & 574.0 \\
TWS-14 & 118.10 & 23.32 & 6.5 & 7.9 & 285.5 \\
TWS-15 & 118.14 & 23.68 & 9.6 & 11.4 & 343.9 \\
TWS-16 & 118.15 & 24.06 & 32.7 & 44.3 & 619.3 \\
TWS-17 & 118.15 & 23.93 & 19.3 & 21.7 & 582.1 \\
TWS-18 & 118.18 & 23.39 & 8.0 & 6.9 & 236.9 \\
TWS-19 & 118.21 & 23.49 & 7.5 & 11.5 & 244.4 \\
\hline & & & & & \\
\hline & & & & & \\
\hline
\end{tabular}




\section{Continued}

\begin{tabular}{|c|c|c|c|c|c|}
\hline TWS-20 & 118.36 & 24.26 & 22.5 & 26.5 & 582.5 \\
\hline TWS-21 & 118.43 & 23.95 & 20.3 & 26.3 & 551.6 \\
\hline TWS-22 & 118.49 & 23.51 & 6.8 & 11.8 & 176.0 \\
\hline TWS-23 & 118.51 & 24.02 & 15.3 & 13.3 & 623.6 \\
\hline TWS-24 & 118.52 & 24.26 & 30.6 & 43.0 & 605.3 \\
\hline TWS-25 & 118.58 & 24.39 & 36.5 & 40.2 & 632.0 \\
\hline TWS-26 & 118.61 & 23.55 & 6.8 & 10.2 & 289.3 \\
\hline TWS-27 & 118.79 & 24.17 & 18.7 & 27.0 & 433.3 \\
\hline TWS-28 & 118.91 & 24.32 & 28.5 & 38.6 & 476.8 \\
\hline TWS-29 & 118.93 & 23.92 & 13.1 & 16.3 & 397.7 \\
\hline TWS-30 & 118.97 & 24.52 & 20.3 & 28.2 & 435.2 \\
\hline TWS-31 & 119.09 & 24.89 & 39.9 & 53.1 & 658.8 \\
\hline TWS-32 & 119.09 & 24.66 & 24.1 & 26.7 & 420.9 \\
\hline TWS-33 & 119.22 & 24.26 & 19.7 & 27.8 & 442.1 \\
\hline TWS-34 & 119.23 & 24.49 & 31.1 & 41.2 & 561.6 \\
\hline TWS-35 & 119.25 & 24.40 & 29.7 & 39.6 & 467.9 \\
\hline TWS-36 & 119.40 & 24.92 & 34.5 & 30.2 & 571.9 \\
\hline TWS-37 & 119.43 & 24.51 & 32.3 & 41.0 & 523.0 \\
\hline TWS-38 & 119.47 & 24.79 & 38.0 & 46.2 & 572.5 \\
\hline TWS-39 & 119.56 & 24.65 & 22.5 & 30.9 & 459.3 \\
\hline TWS-40 & 119.66 & 24.89 & 31.0 & 30.5 & 477.6 \\
\hline TWS-41 & 119.85 & 24.99 & 26.9 & 24.5 & 533.5 \\
\hline \multicolumn{6}{|c|}{ Pearl River Mouth } \\
\hline PRM-1 & 113.47 & 21.18 & 14.0 & 10.1 & 278.1 \\
\hline PRM-2 & 113.47 & 21.42 & 12.2 & 11.4 & 301.3 \\
\hline PRM-3 & 113.54 & 21.65 & 19.1 & 22.1 & 319.0 \\
\hline PRM-4 & 113.55 & 21.42 & 14.9 & 10.9 & 172.8 \\
\hline PRM-5 & 113.65 & 21.31 & 9.4 & 12.8 & 287.1 \\
\hline PRM-6 & 113.71 & 21.48 & 13.1 & 9.0 & 193.2 \\
\hline PRM-7 & 113.76 & 21.42 & 10.9 & 11.1 & 227.0 \\
\hline PRM-8 & 113.94 & 21.42 & 12.2 & 15.7 & 265.5 \\
\hline PRM-9 & 113.47 & 21.59 & 13.8 & 12.0 & 191.1 \\
\hline PRM-10 & 112.67 & 21.00 & 12.2 & 11.7 & 267.2 \\
\hline PRM-11 & 113.76 & 21.42 & 14.1 & 15.2 & 292.4 \\
\hline PRM-12 & 113.65 & 21.54 & 20.0 & 20.1 & 152.0 \\
\hline
\end{tabular}


${ }^{40} \mathrm{~K}$. The gamma ray transitions of energies $186.3 \mathrm{keV}$ and $1460 \mathrm{keV}$ gamma-ray transition were used to determine the concentration of ${ }^{226} \mathrm{Ra}$ and ${ }^{40} \mathrm{~K}$, respectively, while the gamma-ray lines at $911.0 \mathrm{keV}\left({ }^{228} \mathrm{Ac}\right)$ and $583.3 \mathrm{keV}\left({ }^{208} \mathrm{Tl}\right)$ were used to determine the concentration of the ${ }^{232} \mathrm{Th}$ series. The activity levels of the samples obtained for ${ }^{226} \mathrm{Ra},{ }^{232} \mathrm{Th}$ and ${ }^{40} \mathrm{~K}$ are expressed in $\mathrm{Bq} \cdot \mathrm{kg}^{-1}$.

\section{Results and Discussion}

\subsection{Specific Radioactivity}

The activity concentrations of the detected radionuclide ${ }^{226} \mathrm{Ra},{ }^{232} \mathrm{Th}$ and ${ }^{40} \mathrm{~K}$ in the five offshore sand deposits are presented in Table 1.

In the Liaodong Bay, the concentrations of ${ }^{226} \mathrm{Ra},{ }^{232} \mathrm{Th}$ and ${ }^{40} \mathrm{~K}$ vary from 14.7 $\mathrm{Bq} \cdot \mathrm{kg}^{-1}$ to $36.1 \mathrm{~Bq} \cdot \mathrm{kg}^{-1}, 25.3 \mathrm{~Bq} \cdot \mathrm{kg}^{-1}$ to $56.8 \mathrm{~Bq} \cdot \mathrm{kg}^{-1}$ and $405.8 \mathrm{~Bq} \cdot \mathrm{kg}^{-1}$ to 919.4 $\mathrm{Bq} \cdot \mathrm{kg}^{-1}$, with the mean values of $26.5 \mathrm{~Bq} \cdot \mathrm{kg}^{-1}, 41.8 \mathrm{~Bq} \cdot \mathrm{kg}^{-1}$ and $691.9 \mathrm{~Bq} \cdot \mathrm{kg}^{-1}$, respectively.

In the North Yellow Sea, the concentrations of ${ }^{226} \mathrm{Ra},{ }^{232} \mathrm{Th}$ and ${ }^{40} \mathrm{~K}$ vary from $7.2 \mathrm{~Bq} \cdot \mathrm{kg}^{-1}$ to $66.3 \mathrm{~Bq} \cdot \mathrm{kg}^{-1}, 15.7 \mathrm{~Bq} \cdot \mathrm{kg}^{-1}$ to $175.4 \mathrm{~Bq} \cdot \mathrm{kg}^{-1}$ and $635 \mathrm{~Bq} \cdot \mathrm{kg}^{-1}$ to 1044 $\mathrm{Bq} \cdot \mathrm{kg}^{-1}$, with the mean values of $17.5 \mathrm{~Bq} \cdot \mathrm{kg}^{-1}, 39.4 \mathrm{~Bq} \cdot \mathrm{kg}^{-1}$ and $857.1 \mathrm{~Bq} \cdot \mathrm{kg}^{-1}$, respectively.

In the Zhoushan Area, the concentrations of ${ }^{226} \mathrm{Ra},{ }^{232} \mathrm{Th}$ and ${ }^{40} \mathrm{~K}$ vary from 15.0 Bq. $\mathrm{kg}^{-1}$ to $24.0 \mathrm{~Bq} \cdot \mathrm{kg}^{-1}$, 33.0 Bq. $\mathrm{kg}^{-1}$ to $40.0 \mathrm{~Bq} \cdot \mathrm{kg}^{-1}$ and $665.0 \mathrm{~Bq} \cdot \mathrm{kg}^{-1}$ to $836.0 \mathrm{~Bq} \cdot \mathrm{kg}^{-1}$, with the mean values of $19.5 \mathrm{~Bq} \cdot \mathrm{kg}^{-1}, 36.6 \mathrm{~Bq} \cdot \mathrm{kg}^{-1}$ and 728.1 $\mathrm{Bq} \cdot \mathrm{kg}^{-1}$, respectively.

In the Taiwan Shoal, the concentrations of ${ }^{226} \mathrm{Ra},{ }^{232} \mathrm{Th}$ and ${ }^{40} \mathrm{~K}$ vary from 5.6 $\mathrm{Bq} \cdot \mathrm{kg}^{-1}$ to $39.9 \mathrm{~Bq} \cdot \mathrm{kg}^{-1}, 6.5 \mathrm{~Bq} \cdot \mathrm{kg}^{-1}$ to $53.1 \mathrm{~Bq} \cdot \mathrm{kg}^{-1}$ and $176 \mathrm{~Bq} \cdot \mathrm{kg}^{-1}$ to 658.8 $\mathrm{Bq} \cdot \mathrm{kg}^{-1}$, with the mean values of $20.7 \mathrm{~Bq} \cdot \mathrm{kg}^{-1}, 36.3 \mathrm{~Bq} \cdot \mathrm{kg}^{-1}$ and $458.8 \mathrm{~Bq} \cdot \mathrm{kg}^{-1}$, respectively.

In the Pearl River Mouth, the concentrations of ${ }^{226} \mathrm{Ra},{ }^{232} \mathrm{Th}$ and ${ }^{40} \mathrm{~K}$ ranges from 9.4 Bq. $\mathrm{kg}^{-1}$ to $20.0 \mathrm{~Bq} \cdot \mathrm{kg}^{-1}$, 9.0 Bq. $\mathrm{kg}^{-1}$ to $22.0 \mathrm{~Bq} \cdot \mathrm{kg}^{-1}$ and $152.0 \mathrm{~Bq} \cdot \mathrm{kg}^{-1}$ to $319.0 \mathrm{~Bq} \cdot \mathrm{kg}^{-1}$, with the mean values of $13.8 \mathrm{~Bq} \cdot \mathrm{kg}^{-1}, 13.5 \mathrm{~Bq} \cdot \mathrm{kg}^{-1}$ and 245.7 $\mathrm{Bq} \cdot \mathrm{kg}^{-1}$, respectively.

Obviously, the mean concentrations of ${ }^{226} \mathrm{Ra},{ }^{232} \mathrm{Th}$ and ${ }^{40} \mathrm{~K}$ radionuclides from these five sandy deposits are much comparable to those of the world average values of $35 \mathrm{~Bq} \cdot \mathrm{kg}^{-1}, 30 \mathrm{~Bq} \cdot \mathrm{kg}^{-1}$ and $400 \mathrm{~Bq} \cdot \mathrm{kg}^{-1}$ for ${ }^{226} \mathrm{Ra},{ }^{232} \mathrm{Th}$ and ${ }^{40} \mathrm{~K}$, respectively [17] and beach sands around the world (Table 2). The ${ }^{226} \mathrm{Ra}$ concentrations from the five offshore sandy deposits in this study are all lower than that of world average value. However, the ${ }^{40} \mathrm{~K}$ concentrations in Liaodong Bay, North Yellow Sea, Zhoushan Area and Taiwan Shoal are all much higher than that of the world mean value, and the ${ }^{232} \mathrm{Th}$ concentrations from Taiwan Shoal and Pearl River Mouth are lower than that of the world average (Figure 2).

\subsection{Radium Equivalent Activity (Raeq)}

Since the distribution of natural radionuclides in the samples is not uniform, a common radiological index has been introduced to evaluate the actual activity level of ${ }^{226} \mathrm{Ra},{ }^{232} \mathrm{Th}$ and ${ }^{40} \mathrm{~K}$ in the samples and the radiation hazards where 
Table 2. Comparison of activity concentrations of ${ }^{226} \mathrm{Ra},{ }^{232} \mathrm{Th}$, and ${ }^{40} \mathrm{~K}$ dose rates of sandy sediments found in present study and different areas around the world.

\begin{tabular}{|c|c|c|c|c|}
\hline Region/country & ${ }^{226} \mathrm{Ra}$ (range) & ${ }^{232} \mathrm{Th}$ (range) & ${ }^{40} \mathrm{~K}$ (range) & Reference \\
\hline \multicolumn{5}{|l|}{ Beach Sands } \\
\hline Safaga, Egypt & $\begin{array}{c}25.3 \\
(10-64)\end{array}$ & $\begin{array}{c}21.4 \\
(9-37.4)\end{array}$ & $\begin{array}{c}618 \\
(421-969)\end{array}$ & [13] \\
\hline West coast, Thailand & $\begin{array}{c}12.96 \\
(2.7-23.95)\end{array}$ & $\begin{array}{c}19.06 \\
(3-31.2)\end{array}$ & $\begin{array}{c}273.53 \\
(10.7-654.3)\end{array}$ & [12] \\
\hline East Coast, Thailand & $\begin{array}{c}11.13 \\
(3.2-18.6)\end{array}$ & $\begin{array}{c}18.83 \\
(5.1-34.5)\end{array}$ & $\begin{array}{c}414.33 \\
(182.4-559.7)\end{array}$ & {$[12]$} \\
\hline $\begin{array}{l}\text { Patong Beach, Phuket, } \\
\text { Thailand }\end{array}$ & $\begin{array}{c}8.9 \\
(0-67.8)\end{array}$ & $\begin{array}{c}42.4 \\
(0-335.3)\end{array}$ & $\begin{array}{c}963.1 \\
(0-4330.9)\end{array}$ & [18] \\
\hline $\begin{array}{l}\text { Chalatat and Samila Beach } \\
\text { Songkhal, Thailand }\end{array}$ & $\begin{array}{c}41.4 \\
(0-210.8)\end{array}$ & $\begin{array}{c}63.8 \\
(0-318.8)\end{array}$ & $\begin{array}{c}247.8 \\
(89.2-963.4)\end{array}$ & [19] \\
\hline $\begin{array}{l}\text { Northeast coast of } \\
\text { Tamilnadu, India }\end{array}$ & 35.12 & 713.6 & 349.6 & [20] \\
\hline Red Sea coast, Egypt & 21.1 & 11.6 & 930 & [21] \\
\hline Australia & 3.7 & 40 & 44.4 & [22] \\
\hline Brazil & 14.3 & 18 & 807 & [23] \\
\hline $\begin{array}{l}\text { Mediterranean coast, } \\
\text { Turkey }\end{array}$ & 12.2 & 9.0 & 157.7 & [24] \\
\hline Black Sea coast, Turkey & $4.41-14.04$ & $2.62-16.55$ & $11.60-513.32$ & [25] \\
\hline Algiers Bay, Algeria & 15.8 & 19.5 & 374 & [26] \\
\hline Bay of Algeciras, Spain & 12.1 & 15 & 188 & [27] \\
\hline South East Coast, Brazil & $5-4043$ & $7-55537$ & $25-888$ & [28] \\
\hline Preta beach, Brazil & $54-180$ & $128-349$ & $47-283$ & {$[11]$} \\
\hline Dois Rios beach, Brazil & $6-78$ & $12-87$ & $269-527$ & [11] \\
\hline Hongkong & 24.3 & 27.1 & 841 & [29] \\
\hline Xiamen Island, China & $\begin{array}{c}14.6 \\
(7.9-25.7)\end{array}$ & $\begin{array}{c}10.9 \\
(6.7-41.4)\end{array}$ & $\begin{array}{c}396.4 \\
(197.4-487.6)\end{array}$ & [15] \\
\hline Rizhao, China & $\begin{array}{c}12.0 \\
(7.6-17.2)\end{array}$ & $\begin{array}{c}15.2 \\
(7.8-25.1)\end{array}$ & $\begin{array}{c}1079.2 \\
(883.4-1313.6)\end{array}$ & {$[30]$} \\
\hline World & 35 & 30 & 400 & {$[17]$} \\
\hline \multicolumn{5}{|l|}{ Marine Sands (China) } \\
\hline Liaodong Bay & $\begin{array}{c}26.5 \\
(14.7-36.1)\end{array}$ & $\begin{array}{c}41.8 \\
(25.3-56.8)\end{array}$ & $\begin{array}{c}696.9 \\
(405.8-919.4)\end{array}$ & \\
\hline North Yellow Sea & $\begin{array}{c}17.5 \\
(7.2-66.3)\end{array}$ & $\begin{array}{c}39.4 \\
(15.7-175.4)\end{array}$ & $\begin{array}{c}857.1 \\
(635-1044)\end{array}$ & \\
\hline Zhoushan Area & $\begin{array}{c}19.5 \\
(15.0-24.0)\end{array}$ & $\begin{array}{c}36.6 \\
(33.0-40.0)\end{array}$ & $\begin{array}{c}728.1 \\
(665.0-836.0)\end{array}$ & $\begin{array}{l}\text { Present } \\
\text { study }\end{array}$ \\
\hline Taiwan shoal & $\begin{array}{c}20.7 \\
(5.6-39.9)\end{array}$ & $\begin{array}{c}26.3 \\
(6.5-53.1)\end{array}$ & $\begin{array}{c}458.8 \\
(176.0-658.8)\end{array}$ & \\
\hline Pearl river mouth & $\begin{array}{c}13.8 \\
(9.4-20.0)\end{array}$ & $\begin{array}{c}13.5 \\
(9.0-22.0)\end{array}$ & $\begin{array}{c}245.7 \\
(152.0-319.0)\end{array}$ & \\
\hline
\end{tabular}




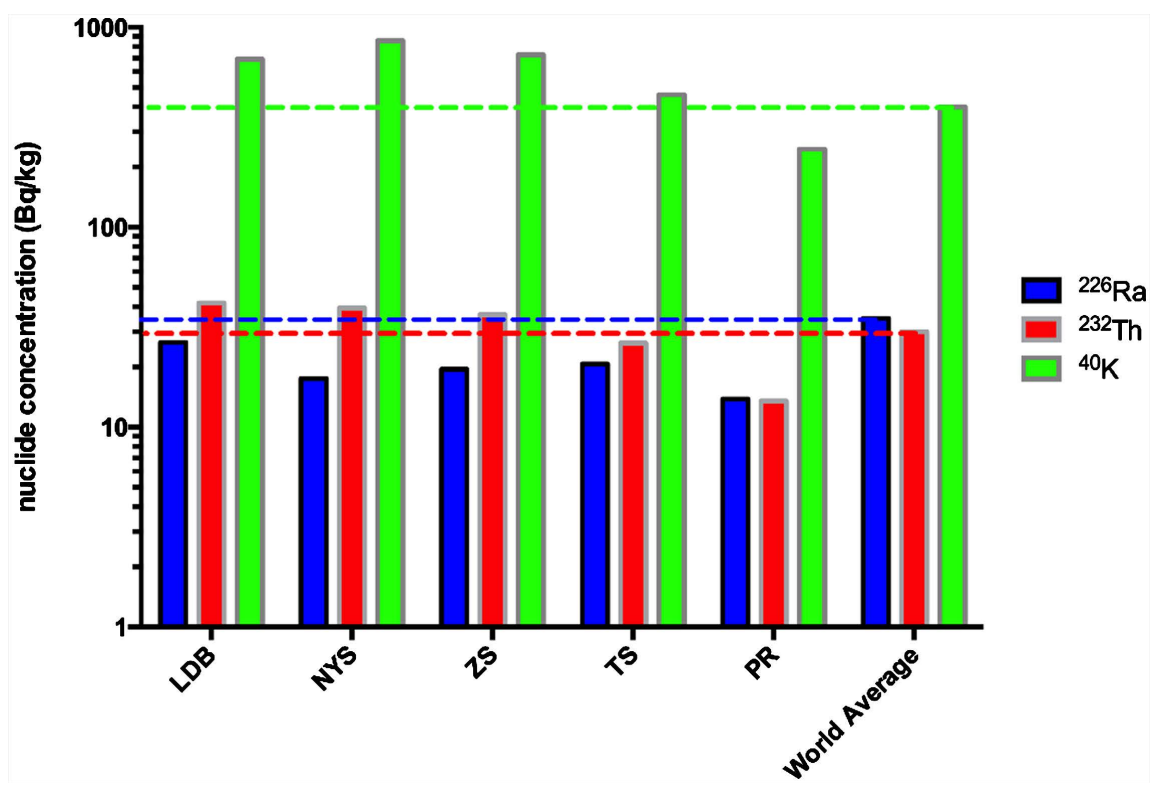

Figure 2. Mean values of ${ }^{226} \mathrm{Ra},{ }^{232} \mathrm{Th}$ and ${ }^{40} \mathrm{~K}$ concentrations in marine sands of Liaodong Bay (LDB), North Yellow Sea (NYS), Zhoushan Area (ZS), Taiwan Shoal (TS), and Pearl River Mouth (PR). The world average values were also shown for comparisons [17], shown as the dashed line for ${ }^{226} \mathrm{Ra}$ (green), ${ }^{232} \mathrm{Th}$ (red) and ${ }^{40} \mathrm{~K}$ (blue), respectively.

associated with these radionuclides, the radium equivalent activity (Raeq), which can be calculated from the relation [22] [31]:

$$
\mathrm{Raeq}=\mathrm{CRa}+1.43 \mathrm{CTh}+0.077 \mathrm{CK}
$$

$\mathrm{CRa}, \mathrm{CTh}$, and $\mathrm{CK}$ are the specific activities of ${ }^{226} \mathrm{Ra},{ }^{232} \mathrm{Th}$ and ${ }^{40} \mathrm{~K}$, respectively, in units of Bq. $\mathrm{kg}^{-1}$. In the definition of the radium equivalent, it is assumed that $10 \mathrm{~Bq} / \mathrm{kg}$ of ${ }^{226} \mathrm{Ra}, 7 \mathrm{~Bq} / \mathrm{kg}$ of ${ }^{232} \mathrm{Th}$ and $130 \mathrm{~Bq} / \mathrm{kg}$ of ${ }^{40} \mathrm{~K}$ each produce an equal gamma-ray dose rate [32] [33].

The calculated values of Raeq for the five sand deposits in investigation are shown in Figure 3. The calculated values of Raeq range from 52.0 (Pearl River Mouth) to 139.8 (North Yellow Sea), with a trend that the Raeq is much higher in North Part of the Chinese Seas than that in the South. All values of Raeq in the studied samples are found to be lower than the criterion limit of $370 \mathrm{~Bq} / \mathrm{kg}$ [34], and therefore, do not pose any radiological hazard when used for construction of buildings.

\subsection{Representative Level Index (RLI)}

In order to estimate the level of gamma radioactivity associated with different concentrations of certain specific radionuclides, known as the representative level index [5] [35], the formula is given as:

$$
\mathrm{RLI}=\mathrm{CRa} / 150+\mathrm{CTh} / 100+\mathrm{CK} / 1500
$$

where CRa, CTh and CK are the average activity concentrations of ${ }^{226} \mathrm{Ra},{ }^{232} \mathrm{Th}$ and ${ }^{40} \mathrm{~K}$, respectively, in units of $\mathrm{Bq} \cdot \mathrm{kg}^{-1}$. The mean RLI values varied from 0.39 (Pearl River Mouth) to 1.08 (North Yeloow Sea) (Figure 4). It is clear that these values do not exceed the upper limit for RLI, which is unity [5]. 


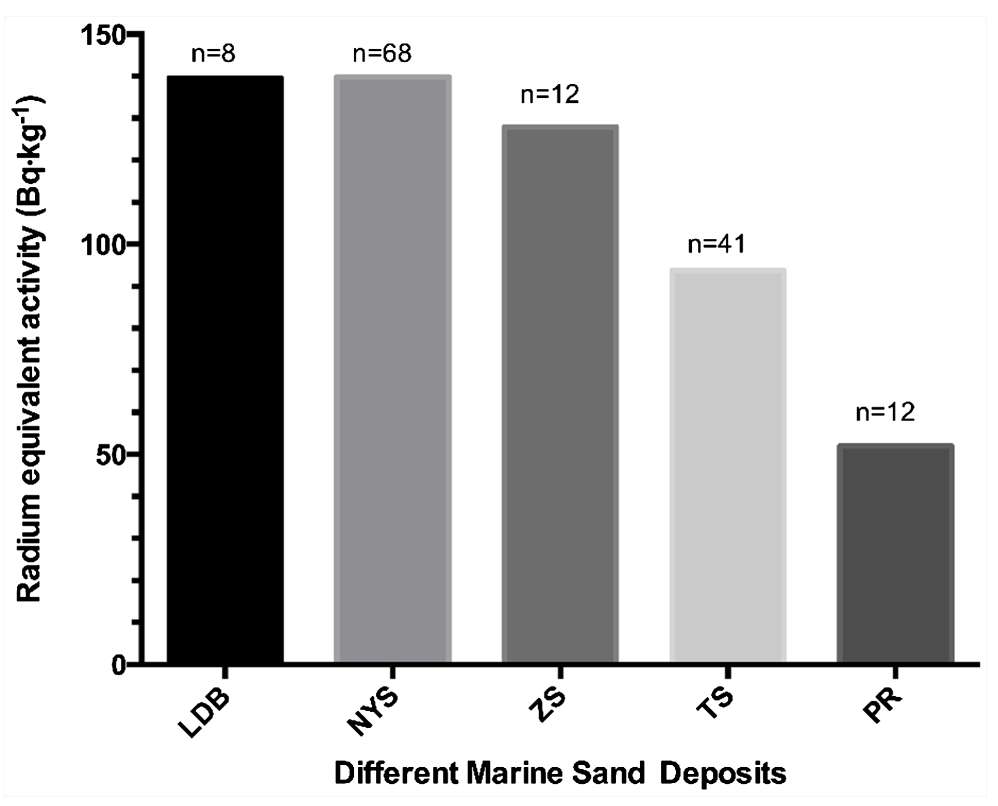

Figure 3. Different marine sands vs. their mean values of radium equivalent $\left(\mathrm{Bq} \cdot \mathrm{kg}^{-1}\right) \cdot \mathrm{n}=$ sample numbers.

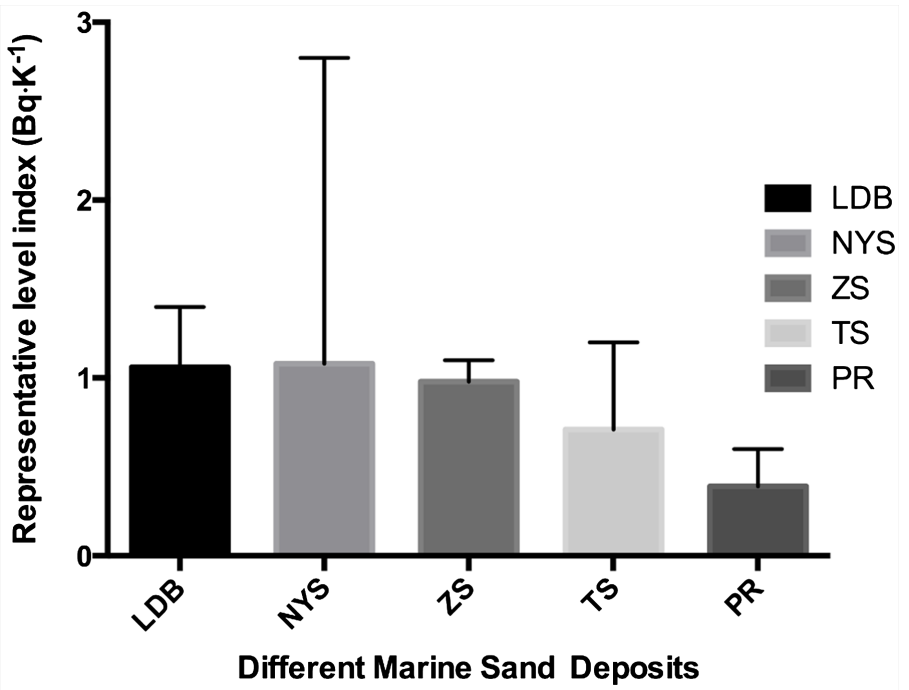

Figure 4. Different marine sand deposits vs. mean (bar) and maximum (line) values of representative level index $\left(\mathrm{Bq} \cdot \mathrm{kg}^{-1}\right)$.

\subsection{Absorbed Gamma Dose Rate (DR), and Annual Effective Dose Rate (HR)}

The absorbed dose rates in indoor air (DR) and the corresponding annual effective doses (HR) attributed to gamma-ray emission from the radionuclides $\left({ }^{226} \mathrm{Ra}\right.$, ${ }^{232} \mathrm{Th}$ and ${ }^{40} \mathrm{~K}$ ) in building materials were evaluated using data and formula provided by UNSCEAR (2000) [17] and the EC (1999) [36]. In the UNSCEAR and EC reports, the dose conversion coefficients were calculated for the center of a standard room with the dimension of $4 \mathrm{~m} * 5 \mathrm{~m} * 2.8 \mathrm{~m}$. The thickness of the walls, floors, ceiling and the density of the structure are $20 \mathrm{~cm}$ and $2350 \mathrm{~kg} / \mathrm{m}^{3}$ (concrete), respectively. The resulting dose coefficients were found to be 0.92 
nGy/h per Bq/kg for ${ }^{226} \mathrm{Ra}, 1.1 \mathrm{nGy} / \mathrm{h}$ per $\mathrm{Bq} / \mathrm{kg}$ for ${ }^{232} \mathrm{Th}$, and $0.080 \mathrm{nGy} / \mathrm{h}$ per $\mathrm{Bq} / \mathrm{kg}$ for ${ }^{40} \mathrm{~K}$ :

$$
\mathrm{DR}(\mathrm{nGy} / \mathrm{h})=0.92 \mathrm{CRa}+1.1 \mathrm{CTh}+0.080 \mathrm{CK}
$$

where CRa, CTh and CK are the activity concentrations of ${ }^{226} \mathrm{Ra},{ }^{232} \mathrm{Th}$ and ${ }^{40} \mathrm{~K}$, respectively.

To estimate the annual effective dose rates, it is necessary to use the conversion coefficient from the absorbed dose in air to the effective dose (0.7 Sv/Gy) and the outdoor occupancy factor (0.2) proposed by UNSCEAR (2000). Therefore, the effective dose rate is determined as follows:

Outdoor $(\mathrm{mSv} / \mathrm{y})=\mathrm{DR}(\mathrm{nGY} / \mathrm{h}) * 24 \mathrm{~h} * 365.25 \mathrm{~d} * 0.2$ (outdoor occupancy factor $) * 0.7 \mathrm{~Sv} \cdot \mathrm{Gy}^{-1}$ (Conversion factor) ${ }^{\star} 10^{-6}$

$$
\mathrm{HR}=\mathrm{DR} * 8766 * 0.2 * 0.7 * 10^{-6}=\mathrm{DR} * 0.00123
$$

where DR is given by Equation (4).

The estimated results of DR and HR for all the studied marine sands range from $31.4 \mathrm{nGy} \cdot \mathrm{h}^{-1}$ (Taiwan Shoal) to $327.1 \mathrm{nGy} \cdot \mathrm{h}^{-1}$ (North Yellow Sea) and from $0.04 \mathrm{mSv} \cdot \mathrm{y}^{-1}$ (Taiwan Shoal) to $0.20 \mathrm{mSv} \cdot \mathrm{y}^{-1}$ (North Yellow Sea), respectively (Figure 5). And the estimated mean value of DR in all of studied samples is 107.9 $\mathrm{nGy} \cdot \mathrm{h}^{-1}$, which is little bit higher than world average indoor absorbed gamma dose rate of $84 \mathrm{nGy} \cdot \mathrm{h}^{-1}$ [17]. Additionally, the estimated mean value of the annual effective dose rate of $0.13 \mathrm{mSv} \cdot \mathrm{y}^{-1}$ is also higher than the world average value $\left(0.07 \mathrm{mSv} \cdot \mathrm{y}^{-1},[17]\right)$.

\subsection{Alpha Index (Ia)}

The alpha index was developed as an assessment of the excess alpha radiation exposure caused by inhalation originating from building materials. The alpha index (Ia) is determined by the following formula [37]:

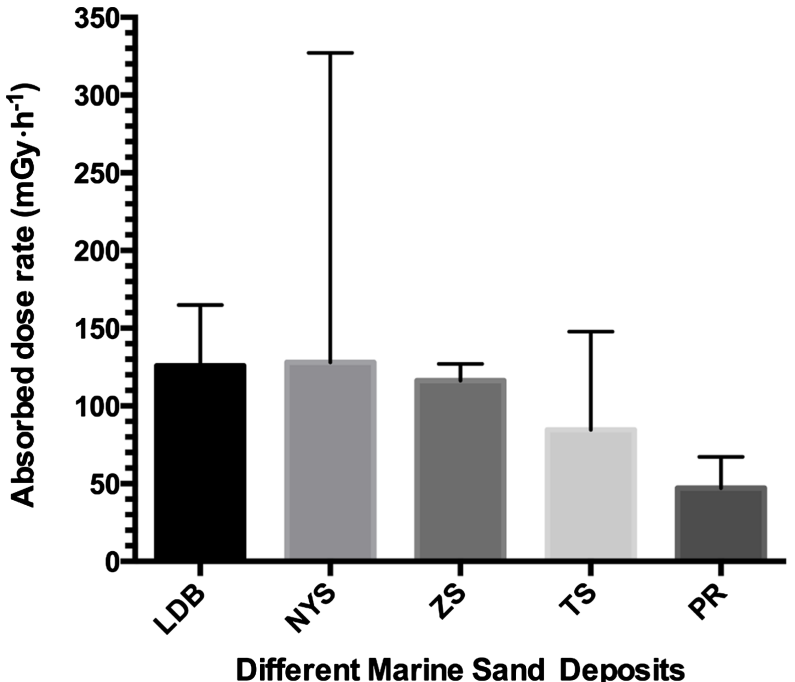

(a)

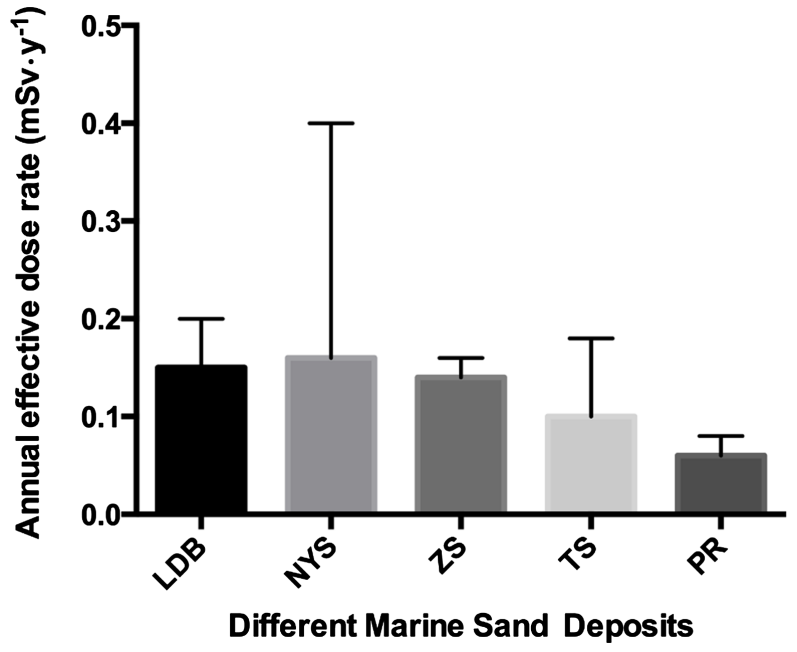

(b)

Figure 5. Different marine sand deposits vs. mean (bar) and maximum (line) values of absorbed dose rate (DR, nGy $\left.\cdot \mathrm{h}^{-1}\right)$ and annual effective dose equivalent $\left(\mathrm{HR}, \mathrm{mSv} \cdot \mathrm{y}^{-1}\right)$. 


$$
\mathrm{Ia}=\mathrm{CRa} / 200(\mathrm{~Bq} / \mathrm{kg})
$$

where $\mathrm{CRa}$ is the ${ }^{226} \mathrm{Ra}$ activity concentration $\left(\mathrm{Bq} \cdot \mathrm{kg}^{-1}\right)$ in the building materials. The recommended exemption level and recommended upper level for the ${ }^{226} \mathrm{Ra}$ activity concentration in building materials as are $100 \mathrm{~Bq} \cdot \mathrm{kg}^{-1}$ and $200 \mathrm{~Bq} \cdot \mathrm{kg}^{-1}$, respectively, as suggested by the Radiation Protection Authorities in Denmark, Finland, Iceland, Norway and Sweden and the upper level is in agreement with the action level given by the ICRP in Publication 65 (1994) and by the European Commission (1990) [39]. It was observed that the values of the alpha index in the studied marine sand samples are below the recommended unity (Figure $6(a))$.

\subsection{Gamma Index (Ig)}

Another radiation hazard index, the gamma activity concentration index, Ig, has been defined by the European Commission (1990) [38] and Righi and Bruzzi (2006) [37], which is given as:

$$
\mathrm{Ig}=\mathrm{CRa} / 300+\mathrm{CTh} / 200+\mathrm{CK} / 3000
$$

The index Ig is corrected with the annual dose rate attributed to excess external gamma radiation caused by superficial material. Values of $\mathrm{Ig} \leq 2$ correspond to the dose rate criterion of $0.3 \mathrm{mSV} \cdot \mathrm{y}^{-1}$, whereas $2<\mathrm{Ig} \leq 6$ correspond to a criterion of $1 \mathrm{mSv} \cdot \mathrm{y}^{-1}$ ([36]). Therefore, the activity concentration index should be used only as a screening tool for identifying materials that might be of concern when used as construction materials; although material with Ig $>6$ should be avoided, in that these values correspond to dose rates higher than $1 \mathrm{mSv} \cdot \mathrm{y}^{-1}$ [36], which is the highest dose rate value recommended for the population [17].

The gamma index Ig for the marine sands varies between 0.13 (Taiwan Shoal) and 0.62 (Taiwan Shoal) with an average of 0.45 (Figure 6(b)). Therefore, these marine sands can be exempted from all restrictions concerning radioactivity.

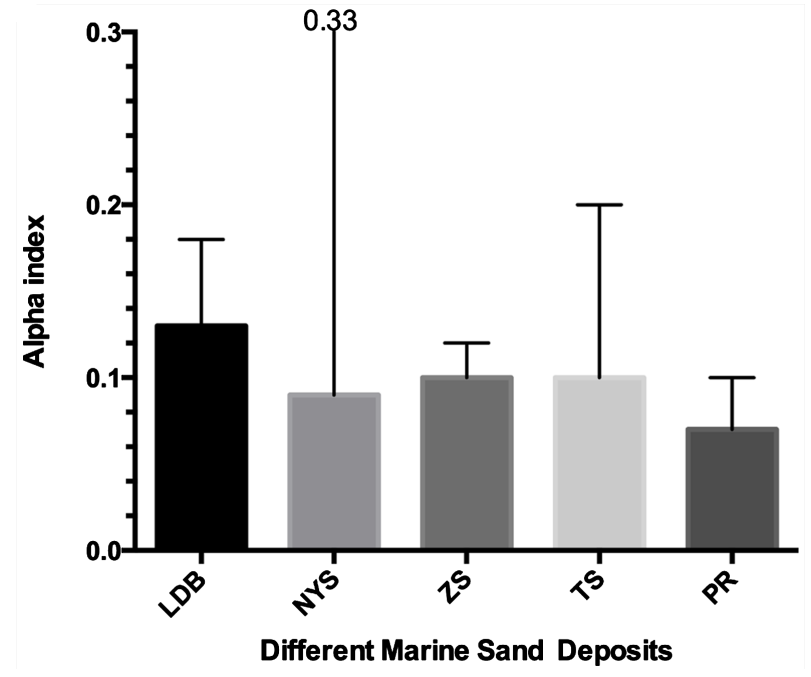

(a)

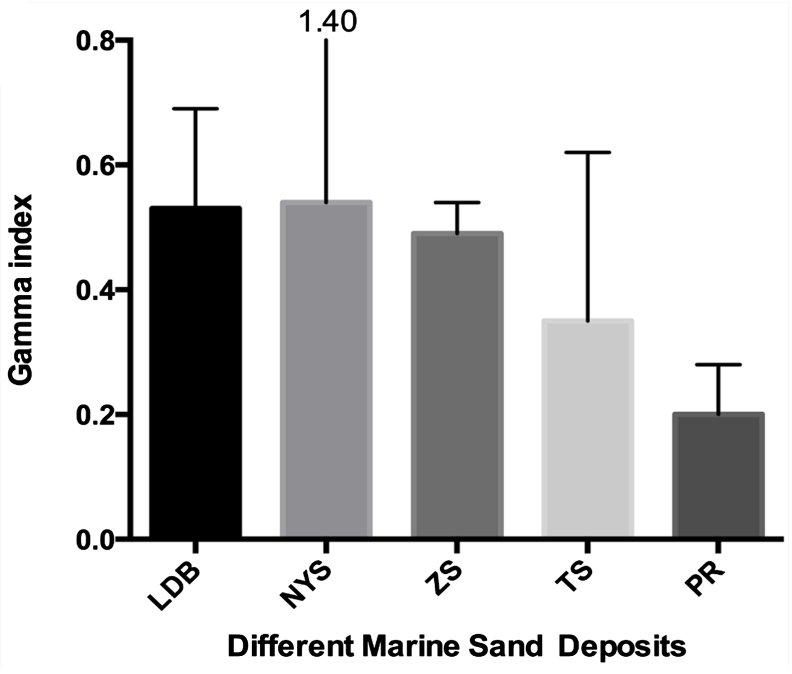

(b)

Figure 6. Mean (bar) and Maximum (line/data) values of alpha index (Ia) and gamma index (Ig) for different marine sand deposits. 


\subsection{Radiation Hazard Indices}

The external radiation hazard (Hex) and the internal radiation hazard, (Hin) was developed for the additional criteria to assess the radiological suitability of a building material [22]. And they are defined as follows:

$$
\text { Hex }=\mathrm{CRa} / 370+\mathrm{CTh} / 258+\mathrm{CK} / 4810
$$

and

$$
\text { Hin }=\mathrm{CRa} / 185+\mathrm{CTh} / 259+\mathrm{CK} / 4810
$$

where $\mathrm{CRa}$, CTh and $\mathrm{CK}$ are the activities of ${ }^{226} \mathrm{Ra},{ }^{232} \mathrm{Th}$ and ${ }^{40} \mathrm{~K}$, respectively, in units of $\mathrm{Bq} \cdot \mathrm{kg}^{-1}$.

The determined values of Hex vary from 0.09 (Taiwan Shoal) to 1.05 (North Yellow Sea) with an average of 0.32 (Figure 7). The Hin values range between 0.11 (Taiwan Shoal) and 1.23 (North Yellow Sea) with an average of 0.37 (Figure 7). However, the highest values of Hex and Hin indices are both found in the same sample from North Yellow Sea, with highest value of ${ }^{226} \mathrm{Ra}$ activity in all samples, which make them larger than 1 (the criterion, [31]).

\subsection{Excess Lifetime Cancer Risk (ELCR)}

The excess lifetime cancer risk (ELCR) was determined using the following equation [39]:

$$
\mathrm{ELCR}=\mathrm{HR} \times \mathrm{DL} \times \mathrm{RF}
$$

where $\mathrm{HR}, \mathrm{DL}$ and $\mathrm{RF}$ are the annual effective dose equivalent, duration of life (70 years) and risk factor $\left(0.05 \mathrm{~Sv}^{-1}\right)$, respectively. The risk factor is defined as the fatal cancer risk per Sievert. For stochastic effects, the ICRP 60 uses a value of 0.05 for the public [39].

The calculated range of ELCR is from $0.14 \times 10^{-3}$ (Taiwan Shoal) to $1.41 \times$ $10^{-3}$ (North Yellow Sea). The average ELCR values for the five marine sand

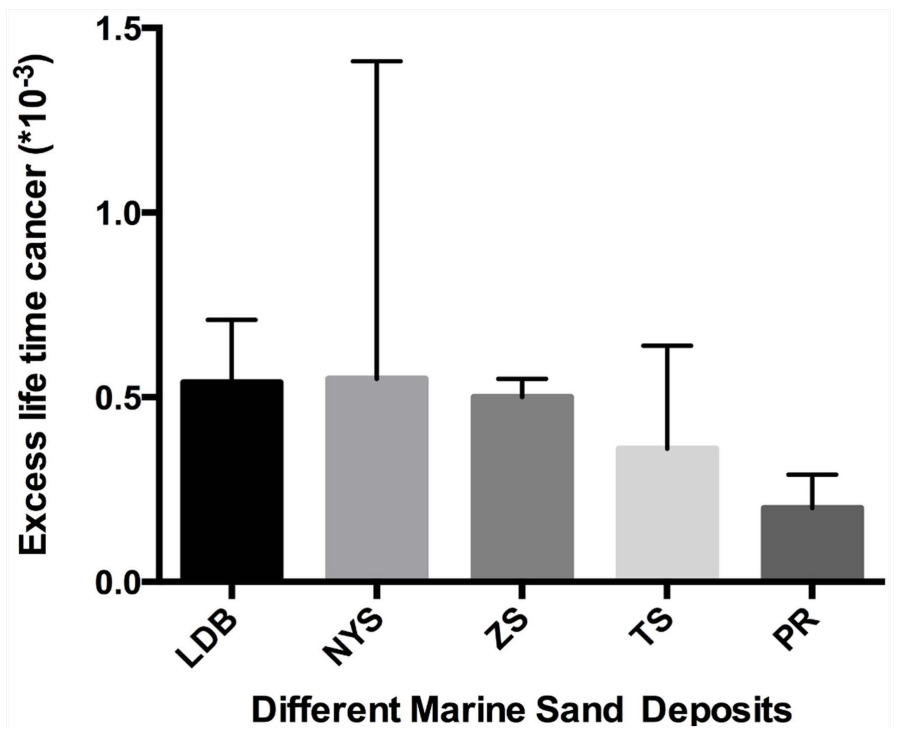

Figure 7. Mean (bar) and maximum (line) values of Hex and Hin of different marine sand deposits. 
deposits are $0.54 \times 10^{-3}$ (Liaodong Bay), $0.55 \times 10^{-3}$ (North Yellow Sea), $0.50 \times$ $10^{-3}$ (Zhoushan), $0.36 \times 10^{-3}$ (Taiwan Shoal) and $0.20 \times 10^{-3}$ (Pearl River Mouth), respectively (Figure 8$)$. And it is very clear that most of the marine sands offshore China is slightly higher than the world average $\left(0.29 \times 10^{-3}\right)$ [17].

\subsection{Annual Gonadal Dose Equivalent (AGDE)}

The activity of bone marrow and bone surface cells are considered to be origins of interest by UNSCER (1988). Therefore, the annual gonadal dose equivalent (AGDE) arising from the specific activities of ${ }^{226} \mathrm{Ra},{ }^{232} \mathrm{Th}$ and ${ }^{40} \mathrm{~K}$ was calculated using the following formula [40]:

$$
\operatorname{AGDE}\left(\mu \mathrm{Sv} \cdot \mathrm{y}^{-1}\right)=3.09 \mathrm{CRa}+4.18 \mathrm{CTh}+0.314 \mathrm{CK}
$$

The mean AGDE values for each marine sand deposit are presented in Figure 9. The values of AGDE varied from 119.0 (Taiwan Shoal) to $1225.0 \mathrm{mSv} \cdot \mathrm{y}^{-1}$

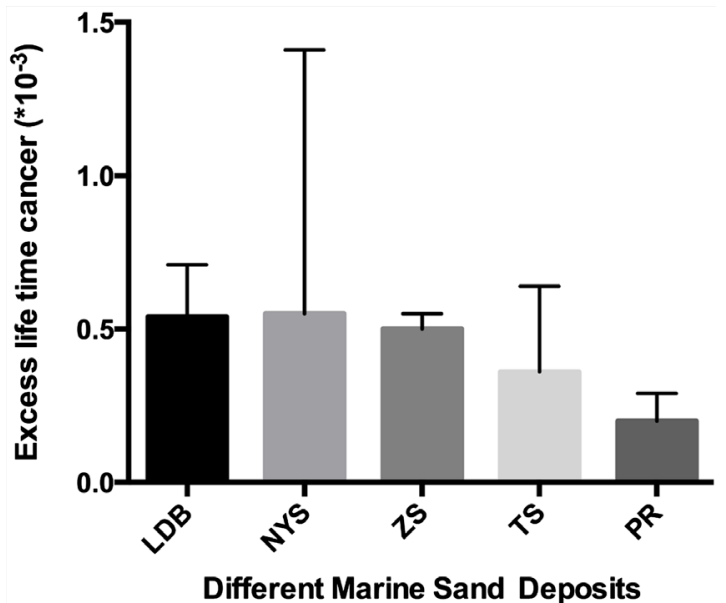

Figure 8. Mean (bar) and maximum (line) values of excess lifetime cancer $\left({ }^{\star} 10^{-3}\right)$ of different marine sands.

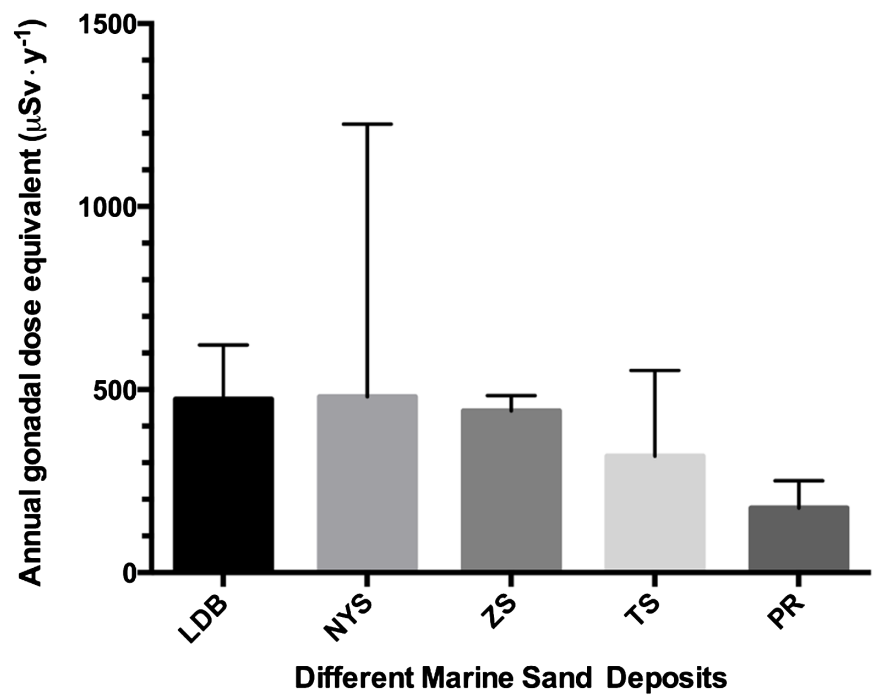

Figure 9. Mean (bar) and Maximum (line) values of annual gonadal dose equivalent $\left(\mathrm{mSv} \cdot \mathrm{y}^{-1}\right)$ for different marine sands. 
(North Yellow Sea) and the average value was found to be $409.0 \mathrm{mSv} \cdot \mathrm{y}^{-1}$. The average values do not generally exceed the permissible recommended limits, indicating that the hazardous effects of the radiation are negligible. In the literature, the average AGDE value for the Eastern Desert of Egypt was found to be $2398 \mathrm{mSv} \cdot \mathrm{y}^{-1}$ [41], for the Tamilnadu of $350.63 \mathrm{mSv} \cdot \mathrm{y}^{-1}$ [42], for the Firtına Valley (Turkey) of $550.5 \mathrm{mSv} \cdot \mathrm{y}^{-1}$ [43].

\subsection{Multivariate Statistical Analysis}

Correlation analysis was carried out in terms of bivariate statistics to determine the mutual relations and strengths of association between pairs of variables through the calculation of the linear Pearson correlation coefficients. The results for Pearson correlation coefficients between all the studied radioactive variables of the marine sand deposits offshore China are shown in Table 3.

A high positive correlation coefficient is observed between ${ }^{232} \mathrm{Th}$ and ${ }^{226} \mathrm{Ra}$ (Figure 10(a)), because the radium and thorium decay series occur together in nature [42]. In contrast, a very weak negative correlation coefficient was observed between these two nuclides and ${ }^{40} \mathrm{~K}$ (Figure 10(b) and Figure 10(c)), because ${ }^{40} \mathrm{~K}$ is from different origin [42]. In addition, all radioactive variables have strong positive correlation coefficients with ${ }^{226} \mathrm{Ra}$ and ${ }^{232} \mathrm{Th}$, while they are weakly negatively correlated with ${ }^{40} \mathrm{~K}$. All radioactive variables calculated are positively correlated with one another (Table 3).

Principal component analysis was performed on the whole data set (13 variables) to assess the relations between them. The rotated factor analysis was carried out via varimax rotation with Kaiser normalization. The rotated factor 1 and factor 2 values are shown in Table 4. Two principal components were yielded with eigenvalues $>1$, explaining $98.26 \%$ of the total variance. From the

Table 3. Pearson correlation matrix among the variables.

\begin{tabular}{|c|c|c|c|c|c|c|c|c|c|c|c|c|c|}
\hline Variables & ${ }^{226} \mathrm{Ra}$ & ${ }^{232} \mathrm{Th}$ & ${ }^{40} \mathrm{~K}$ & $\mathrm{Ra}_{\mathrm{eq}}$ & RLI & $\mathrm{D}_{\mathrm{R}}$ & $\mathrm{H}_{\mathrm{R}}$ & $\mathrm{I}_{\mathrm{a}}$ & $I_{g}$ & $\mathrm{H}_{\mathrm{ex}}$ & $\mathrm{H}_{\mathrm{in}}$ & ELCR & AGDE \\
\hline${ }^{226} \mathrm{Ra}$ & 1.00 & & & & & & & & & & & & \\
\hline${ }^{232} \mathrm{Th}$ & 0.79 & 1.00 & & & & & & & & & & & \\
\hline${ }^{40} \mathrm{~K}$ & 0.12 & 0.46 & 1.00 & & & & & & & & & & \\
\hline $\mathrm{Ra}_{\mathrm{eq}}$ & 0.74 & 0.95 & 0.69 & 1.00 & & & & & & & & & \\
\hline RLI & 0.70 & 0.93 & 0.74 & 1.00 & 1.00 & & & & & & & & \\
\hline$D_{R}$ & 0.71 & 0.93 & 0.74 & 1.00 & 1.00 & 1.00 & & & & & & & \\
\hline $\mathrm{H}_{\mathrm{R}}$ & 0.71 & 0.93 & 0.74 & 1.00 & 1.00 & 1.00 & 1.00 & & & & & & \\
\hline Ia & 0.99 & 0.79 & 0.12 & 0.74 & 0.70 & 0.71 & 0.70 & 1.00 & & & & & \\
\hline Ig & 0.70 & 0.93 & 0.74 & 1.00 & 1.00 & 1.00 & 1.00 & 0.70 & 1.00 & & & & \\
\hline $\mathrm{H}_{\mathrm{ex}}$ & 0.74 & 0.95 & 0.69 & 1.00 & 1.00 & 1.00 & 1.00 & 0.74 & 0.98 & 1.00 & & & \\
\hline $\mathrm{H}_{\text {in }}$ & 0.82 & 0.96 & 0.62 & 1.00 & 0.98 & 0.98 & 0.98 & 0.82 & 1.00 & 0.99 & 1.00 & & \\
\hline ELCR & 0.69 & 0.92 & 0.76 & 0.99 & 1.00 & 1.00 & 1.00 & 0.69 & 1.00 & 0.98 & 1.00 & 1.00 & \\
\hline AGDE & 0.71 & 0.93 & 0.74 & 1.00 & 1.00 & 1.00 & 1.00 & 0.71 & 1.00 & 0.98 & 1.00 & 1.00 & 1.00 \\
\hline
\end{tabular}




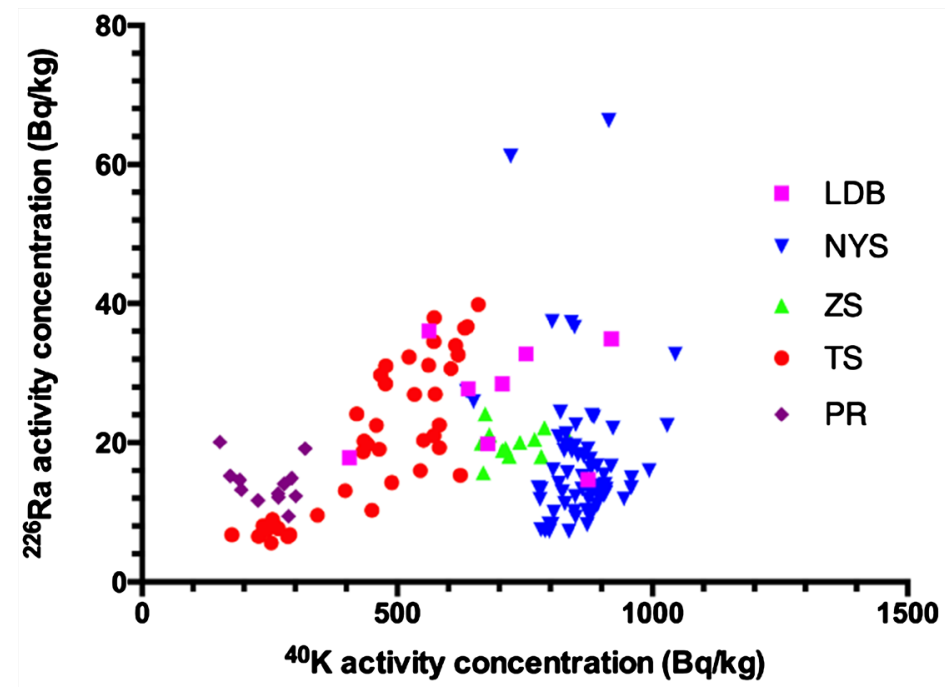

(a)

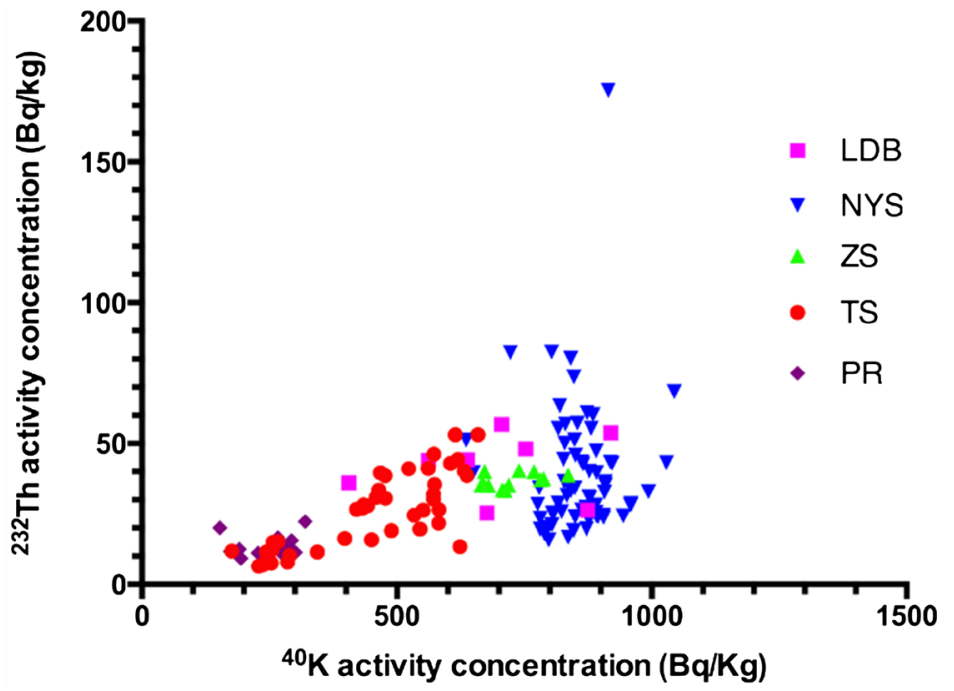

(b)

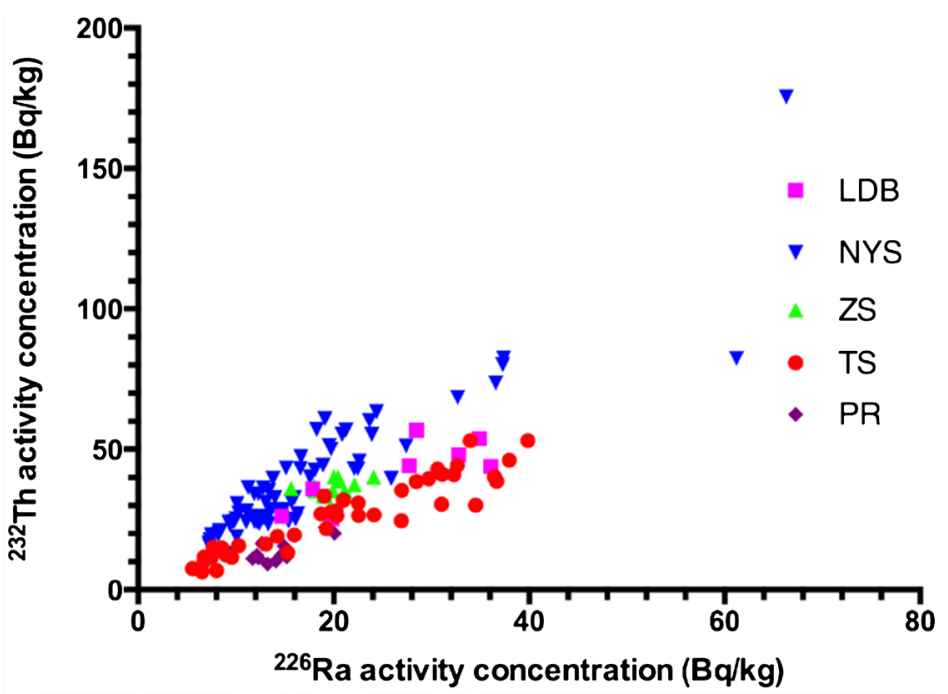

(c)

Figure 10. Correlation scatter plots between the radionuclide concentrations of ${ }^{226} \mathrm{Ra}$, ${ }^{232} \mathrm{Th}$ and ${ }^{40} \mathrm{~K}$. A, ${ }^{40} \mathrm{~K}$ vs. ${ }^{226} \mathrm{Ra}$; B, ${ }^{40} \mathrm{~K}$ vs. ${ }^{232} \mathrm{Th}$; C, ${ }^{226} \mathrm{Ra}$ vs. ${ }^{232} \mathrm{Th}$. 
Table 4. Rotated factor loading of the variables.

\begin{tabular}{ccc}
\hline & \multicolumn{2}{c}{ Component } \\
\cline { 2 - 3 } Variables & 1 & 2 \\
\hline${ }^{226} \mathrm{Ra}$ & 0.238 & 0.958 \\
${ }^{232} \mathrm{Th}$ & 0.653 & 0.71 \\
${ }^{40} \mathrm{~K}$ & 0.964 & -0.143 \\
$\mathrm{Ra}_{\mathrm{eq}}$ & 0.816 & 0.576 \\
$\mathrm{RLI}$ & 0.852 & 0.523 \\
$\mathrm{D}_{\mathrm{R}}$ & 0.848 & 0.529 \\
$\mathrm{H}_{\mathrm{R}}$ & 0.849 & 0.525 \\
$\mathrm{I}_{\mathrm{a}}$ & 0.236 & 0.959 \\
$\mathrm{I}_{\mathrm{g}}$ & 0.852 & 0.523 \\
$\mathrm{H}_{\mathrm{ex}}$ & 0.816 & 0.577 \\
$\mathrm{H}_{\mathrm{in}}$ & 0.742 & 0.67 \\
$\mathrm{ELCR}$ & 0.863 & 0.506 \\
$\mathrm{AGDE}$ & 0.848 & 0.529 \\
\hline
\end{tabular}

rotation space of component 1 and the component 2 (Figure 11), the first component accounts for $88.22 \%$ of the total variance and is mainly characterized by high positive loadings of concentration of ${ }^{40} \mathrm{~K},{ }^{232} \mathrm{Th}$ and most of the radioactive variables. While the second component accounts for $10.41 \%$ of the total variance and is mainly corresponds to positive loading of ${ }^{226} \mathrm{Ra}$ and Ia. From the overall component analysis, it can be deduced that ${ }^{40} \mathrm{~K}$ and ${ }^{232} \mathrm{Th}$ dominantly increase the radioactivity in the entire marine sand deposits offshore China.

\section{Conclusion}

The natural radionuclide content, radium equivalent activity (Raeq), indoor gamma absorbed dose rate (DR), annual effective dose (HR), alpha index (Ia), gamma index (Ig), external radiation hazard level index (RLI), excess lifetime cancer risk (ELCR) and annual gonadal dose equivalent (AGDE) of five marine sand deposits offshore China were determined. The values obtained in the present study are mostly within the recommended safety limits in spite of just one sample from North Yellow Sea, demonstrating that these marine sands will not pose any significant radiation hazard; thus, the use of these marine sands even in the construction of buildings can be considered safe for the human being. From the statistical analysis, the marine sands in the northern part of offshore China (Liaodong Bay, North Yellow Sea) have ${ }^{226} \mathrm{Ra},{ }^{232} \mathrm{Th}$ and ${ }^{40} \mathrm{~K}$ concentrations that are higher than those from southern part of offshore China (Zhoushan, Taiwan Shoal and Pearl River Mouth). In addition, ${ }^{40} \mathrm{~K}$ and ${ }^{232} \mathrm{Th}$ are primarily responsible for radioactivity levels of marine sands offshore China. 


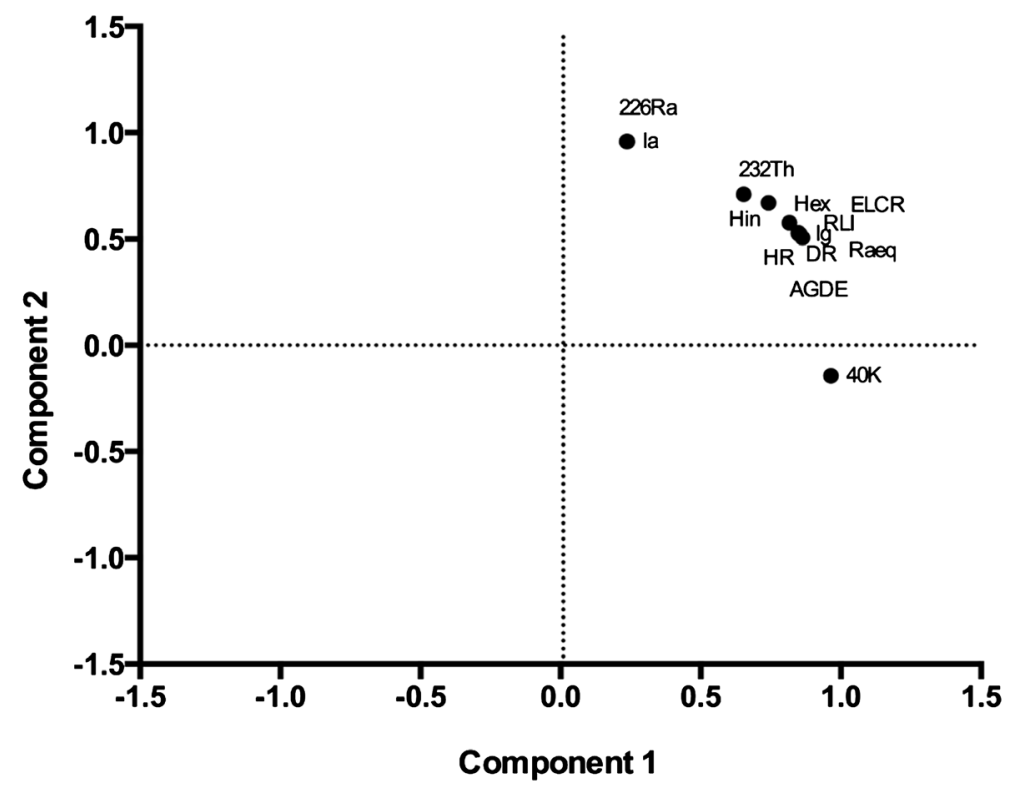

(a)

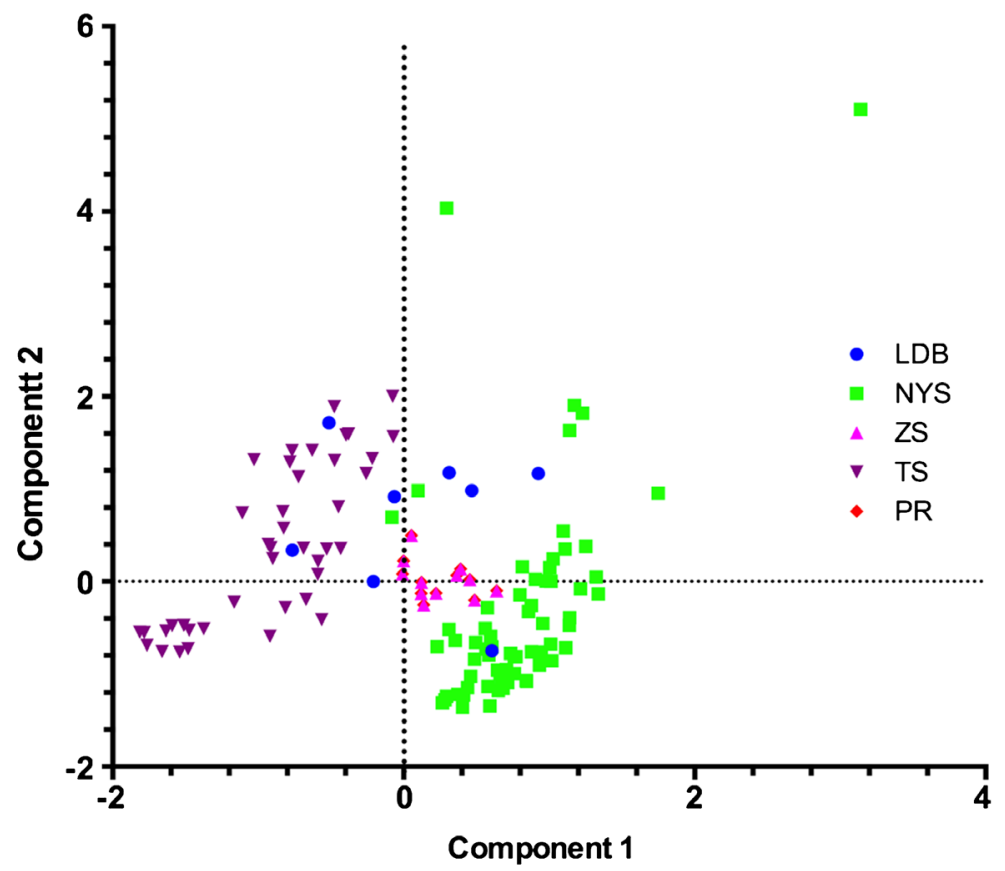

(b)

Figure 11. Graphical representations of component 1 and Component 2 (a) and factor loadings for each sample from different marine sands (b).

\section{Acknowledgements}

This research was financially supported by the Natural Science Foundation of China (No. 41476052, 40976036, 41376096).

\section{References}

[1] Cho, D. (2006) Challenges to Sustainable Development of Marine Sand in Korea. Ocean and Coastal Management, 49, 1-21.

[2] Zhang, Q., Wang, P., Wang, W. and Zhang, Y. (2010) Marine Sand Resources in the 
Pearl River Estuary Waters of China. Journal of Marine Systems, 82S, S83-S89.

[3] Zhao, M., Yang, D., Wang, P. and Shi, P. (2015) A Market-Based Approach to Marine Sand Resource Management in the Pearl River Estuary, China. Ocean \& Coastal Management, 105, 56-64.

[4] Williams, S.J., Reid, J.M. and Manheim, F.T. (2003) A Bibliography of Selected References to U.S. Marine Sand and Gravel Mineral Resources. U.S. Geological Survey Open-File Report 03-300, 1-67.

[5] Alam, M.N., Chowdhury, M.I., Kamal, M., Ghose, S., Islam, M.N., Mustafa, M.N., Miah, M.M.H. and Ansary, M.M. (1999) The ${ }^{226} \mathrm{Ra},{ }^{232} \mathrm{Th}$ and ${ }^{40} \mathrm{~K}$ Activities in Beach Sand Minerals and Beach Soils of Cox's Bazaar, Bangladesh. Journal of Environmental Radioactivity, 46, 243-250.

[6] Hamadneh, H.S., Ababneh, Z.Q., Hmasha, K.M. and Ababneh, A.M. (2015) The Radioactivity of Seasonal Dust Storms in the Middle East: The May 2012 Case Study in Jordan. Journal of Environmental Radioactivity, 140, 65-69.

[7] Rizzo, S., Brai, M., Basile, S., Bellia, S. and Hauser, S. (2001) Gamma Activity and Geochemical Features of Building Materials: Estimation of Gamma Dose Rate and Indoor Radon Levels in Sicilly. Applied Radiation and Isotopes, 55, 259-265.

[8] Kannan, V., Rajan, M.P., Iyengar, M.A.R. and Ramesh, R. (2002) Distribution of Natural and Anthropogenic Radionuclides in Soil and Sand Samples of Kalpakkam (India) Using Hyper Pure Germanium (HPGe) Gamma Ray Spectrometry. Applied Radiation and Isotopes, 57, 109-119.

[9] Ravisankar, R., Vanasundari, K., Chandrasekaran, A., Rajalakshmi, A., Suganya, M., Vijayagopal, P. and Meenakshisundaram, V. (2012) Measurement of Natural Radioactivity in Building Materials of Namakkal, Tamil Nadu, India Using Gamma-Ray Spectrometry. Applied Radiation and Isotopes, 70, 699-704.

[10] Alencar, A.S. and Freitas, A.C. (2005) Reference Levels of Natural Radioactivity for the Beach Sands in a Brazilian Southeastern Coastal Region. Radiation Measurements, 40, 76-83.

[11] Freitas, A.C. and Alencar, A.S, (2004) Gamma Dose Rates and Distribution of Natural Radionuclides in Sand Beaches-Ilha Grande, Southeastern Brazil. Journal Environmental Radioactivity, 75, 211-223.

[12] Malain, D., Regan, P.H., Bradley, D.A., Matthews, M., Al-Sulaiti, H.A. and Santawamaitre, T. (2012) An Evaluation of the Natural Radioactivity in Andaman Beach Sand Samples of Thailand after the 2004 Tsunami. Applied Radiation and Isotopes, 70, 1467-1474.

[13] El-Arabi, A.M. (2005) Natural Radioacitivity in Sand in Thermal Therapy at the Red Sea Coast. Journal of Environmental Radioactivity, 81, 11-19.

[14] Tari, M., Zarandi, S.A., Mohammadi, K. and Zare, M.R. (2013) The Measurement of Gamma-Emitting Radionuclides in Beach Sand Cores of Coastal Regions of Ramsar, Iran Using HPG3 Detectors. Marine Pollution Bulletin, 74, 425-434.

[15] Huang, Y., Lu, X., Ding, X. and Feng, T. (2015) Natural Radioactivity Level in Beach Sand along the Coast of Xiamen Island, China. Marine Pollution Bulletin, 91, 357-361.

[16] Mollah, A.S., Ahmad, G.U., Husain, S.R. and Rahman, M.M. (1986) The Natural Radioactivity of Some Building Materials Used in Bangladesh. Health Physics, 50, 849-851.

[17] United National Scientific Committee on the Effects of Atomic Radiation (UNSCEAR) (2000) Sources and Risks of Ionizing Radiation. Report to the General Assembly with Annexes, United Nations, New York. 
[18] Kessaratikoon, P., Boonkrongcheep, R., Benjakul, S. and Youngchauy, U. (2013) Specific Activities and Radioactive Contour Maps of Natural and Anthropogenic Radionuclides in Beach Sand Samples (Patong, Kamala, Kata, Karon and Nai Yang) after Tsunami Disaster in Phuket Province, Thailand. Journal of Radioactive Nuclear Chemistry, 297, 247-255. https://doi.org/10.1007/s10967-012-2384-8

[19] Benjakul, S., et al. (2007) Natural Radionuclide Distribution in Soil from Muang District in Songkhla Province. MSc. Thesis, Thaksin University, Thailand.

[20] SureshGandhi, M., Ravisankar, R., Rajalakshmi, A., Sivakumar, S., Chandrasekaran, A. and PreamAnand, D. (2014) Measurement of Natural Gamma Radiation in Beach Sediments of North East Coast of Taminadu, India by Gamma Ray Spectrometry with Multivariate Statistical Approach. Journal of Radiation Research and Applied Sciences, 7, 7-17.

[21] Hurb, S. (2008) Natural Radioactivity and External Gamma Radiation Exposure at the Coastal Red Sea in Egypt. Radiation Protection Dosimetry, 130, 376-384. https://doi.org/10.1093/rpd/ncn064

[22] Beretka, J. and Mathew, P.J. (1985) Natural Radioactivity of Australian Building Materials, Industrial Waters and By-Products. Healthy Physics, 48, 87-95. https://doi.org/10.1097/00004032-198501000-00007

[23] Malanca, A., Pessina, V. and Dallara, G. (1993) Radionuclide Content of Building Materials and Gamma Ray Dose Rates in Dwellings of Rio Grande Do Norte. Brazil. Radiation Protection Dosimetry, 48, 199-203.

[24] Özmen, S.F., Cesur, A., Boztosun, I. and Yavuz, M. (2014) Distribution of Natural and Anthropogenic Redionuclides in Beach sand Samples from Mediterranean Coast of Turkey. Radiation Physics and Chemistry, 103, 37-44.

[25] Korkulu, Z. and Özkan, N. (2013) Determination of Natural Radioactivity Levels of Beach Sand Samples in the Black Sea Coast of Kocaeli (Turkey). Radiation Physics and Chemistry, 88, 27-31.

[26] Benamar, M.A., Zerrouki, A., Idiri, Z. and Tobbeche, S. (1997) Natural and Artificial Levels in Sediments in Algiers Bay. Applied Radiation and Isotopes, 48, 1161 164.

[27] González-Fernández, D., Garrido-Pérez, M.C., Casas-Ruiz, M., Barbero, L. and Nebot-Sanz, E. (2012) Radiological Risk Assessment of Naturally Occurring Radioactive Materials in Marine Sediments and Its Application in Industrialized Coastal Areas: Bay of Algeciras. Environmental Earth Sciences, 66, 1175-1181.

[28] Veiga, R., Sanches, N., Anjos, R.M., Macario, K., Bastos, J., Iguatemy, M., Aguiar, J.G., Santos, A.M.A., Mosquera, B., Carvalho, C., BaptistaFilho, M. and Umisedo, N.K. (2006) Measurement of Natural Radioactivity in Brazillian Beach Sands. Radiation Measurements, 41, 189-196.

[29] Yu, K.N., Guan, Z.J., Stokes, M.J. and Young, E.C.M. (1992) The Assessment of the Natural Radiation Dose Committed to the Hong Kong People. Journal of Environmental Radioactivity, 17, 31-48.

[30] Lu X. and Zhang X. (2008) Measurement of Natural Radioactivity in Beach Sands from Rizhao Bathing Beach, China. Radiation Protection Dosimetry, 130, 385-388. https://doi.org/10.1093/rpd/ncn053

[31] Krieger, R. (1981) Radioactivity of Construction Materials. Betonwerk FertigteilTechnik, 47, 468-473.

[32] Krisiuk, E.M., Tarasov, S.I., Shamov, V.P., Shlak, N.I., Lisachenko, E.P. and Gomslsky, L.G. (1971) A Study of Radioactivity in Building Materials. Research Institute of Radiation Hygeine Leningrad.

[33] Stranden, E. (1976) Some Aspects on Radioactivity of Building Materials. Pyhsica 
Norvegica, 8, 167-173.

[34] NEA-OECD (1979) Exposure to Radiation from Natural Radioactivity in Building Materials. Report by NEA Group of Experts of the Nuclear Energy Agency, OECD, Paris, France.

[35] Abbady, A.G. (2004) Estimation of Radiation Hazard Indices from Sedimentary Rocks in Upper Egypt. Applied Radiation and Isotopes, 60, 111-114.

[36] EC (European Commission) (1999) Radiation Protection, 112-Radiological Protection Principles Concerning the Natural Radioactivity of Building Materials. Directorate-General Environment, Nuclear Safety and Civil Protection.

[37] Righi, S. and Bruzzi, L. (2006) Natural Radioactivity and Radon Exhalation in Building Materials Used in Italian Dwellings. Journal of Environmental Radioactivity, 88, 158-170.

[38] EC (European Commission) (1990) Commission Recommendation 90/143/Euratom of 21 February 1990 on the Protection of the Public against Indoor Exposure to Radon. Official Journal L-80 of 27/03/90, European Commission, Brussels.

[39] Taskin, H., Karavus, M., Ay, P., Topuzoglu, A., Hidiroglu, S. and Karahan, G. (2009) Radionuclide Concentrations in Soil and Lifetime Cancer Risk Due to Gamma Radioactivity in Kirklareli, Turkey. Journal of Environmental Radioactivity, 100, 49-53.

[40] Mamont-Ciesla, K., Gwiazdowski, B., Biernacka, M. and Zak, A. (1982) Radioactivity of Building Materials in Poland. In: Vohra, G., Pillai, K.C. and Sadavisan, S., Eds., Natural Radiation Environment, Halsted Press, New York, 551.

[41] Arafa, W. (2004) Specific Activity and Hazards of Granite Samples Collected from the Eastern Desert of Egypt. Journal of Environmental Radioactivity, 75, 315-327.

[42] Ravisankar, R., Vanasundari, K., Suganya, M., Raghu, Y., Rajalakshmi, A., Chandrasekaran, A., Sivakumar, S., Chandramohan, J., Vijayagopal, P. and Venkatraman, B. (2014) Multivariate Statistical Analysis of Radiological Data of Building Material Used in Tiruvannamalai, Tamilnadu, India. Applied Radiation and Isotopes, 85, 114-127.

[43] Kurnaz, A., Küçükömeroğlu, B., Keser, R., Okumusoglu, N.T., Forkmaz, F., Karahan, G. and Çevik, U. (2007) Determination of Radioactivity Levels and Hazards of Soil and Sediment Samples in Firtına Valley (Rize, Turkey). Applied Radiation and Isotopes, 65, 1281-1289.

\section{Submit or recommend next manuscript to SCIRP and we will provide best service for you:}

Accepting pre-submission inquiries through Email, Facebook, LinkedIn, Twitter, etc. A wide selection of journals (inclusive of 9 subjects, more than 200 journals)

Providing 24-hour high-quality service

User-friendly online submission system

Fair and swift peer-review system

Efficient typesetting and proofreading procedure

Display of the result of downloads and visits, as well as the number of cited articles

Maximum dissemination of your research work

Submit your manuscript at: http://papersubmission.scirp.org/

Or contact ojms@scirp.org 